\title{
WestVirginiaUniversity
}

THE RESEARCH REPOSITORY @ WVU

Graduate Theses, Dissertations, and Problem Reports

2013

\section{Completion Rates in West Virginia Community and Technical Colleges}

Angelic M. Kinder

West Virginia University

Follow this and additional works at: https://researchrepository.wvu.edu/etd

\section{Recommended Citation}

Kinder, Angelic M., "Completion Rates in West Virginia Community and Technical Colleges" (2013).

Graduate Theses, Dissertations, and Problem Reports. 3636.

https://researchrepository.wvu.edu/etd/3636

This Dissertation is protected by copyright and/or related rights. It has been brought to you by the The Research Repository @ WVU with permission from the rights-holder(s). You are free to use this Dissertation in any way that is permitted by the copyright and related rights legislation that applies to your use. For other uses you must obtain permission from the rights-holder(s) directly, unless additional rights are indicated by a Creative Commons license in the record and/ or on the work itself. This Dissertation has been accepted for inclusion in WVU Graduate Theses, Dissertations, and Problem Reports collection by an authorized administrator of The Research Repository @ WVU.

For more information, please contact researchrepository@mail.wvu.edu. 
Completion Rates in West Virginia Community and Technical Colleges

Angelic M. Kinder

Dissertation submitted to the College of Education and Human Services at West Virginia University in partial fulfillment for the requirements for the degree of

\title{
Educational Doctorate
}

in

Higher Education Administration

\author{
Richard T. Walls, Ph.D., Chair \\ Dr. Samuel F. Stack, Ph.D. \\ Dr. Keith D. Weber, Ed.D. \\ Dr. Peter G. Checkovich, Ed.D.
}

\author{
Morgantown, West Virginia \\ 2013
}




\section{Abstract \\ Completion Rates in West Virginia Community and Technical Colleges \\ Angelic M. Kinder}

This research examined withdrawal and completion rates in courses at public community colleges in West Virginia during the Fall 2009 and Fall 2010 semesters. Online distance education has quickly gained popularity over the previous ten years, and the number of students enrolling in online education has increased at a higher rate than overall enrollment in higher education. Few studies have analyzed withdrawal and completion rates specifically in online courses. Why is student attrition so high? How does this vary from traditional face-toface courses? What can institutions do to prevent online students from withdrawing and not completing courses?

This study performed a comparative analysis based on existing data for which the West Virginia Community and Technical College System (WVCTCS) institutions provide information for reporting each semester. Data that can identify the student was removed, and the remaining data compared to determine the types of courses that have the highest withdrawal and failure rates.

A total of 148,939 records were analyzed from all students enrolled in community and technical college courses across the State of West Virginia during the Fall 2009 and Fall 2010 semesters. Traditional courses consisted of $86.1 \%$ of the courses, $2.0 \%$ were hybrid, and $11.9 \%$ were online. This study only looks at how many students are withdrawing and not passing online courses at West Virginia Community and Technical Colleges, it does not look into why these students withdraw at a higher rate than traditional courses. Further research is needed on the reasons why they withdraw and what can be done to prevent their departure. 


\section{Table of Contents}

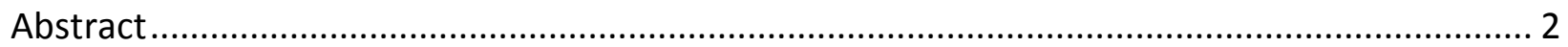

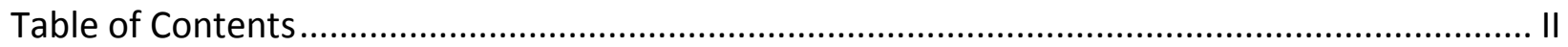

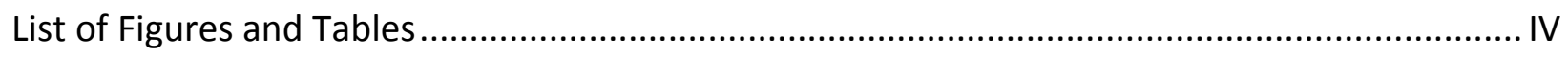

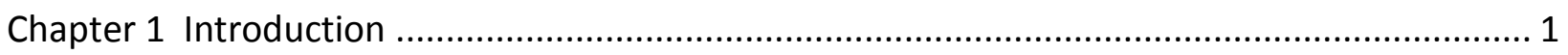

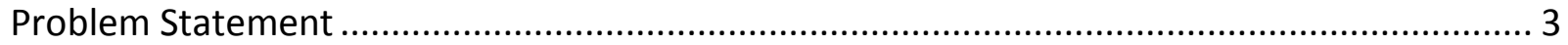

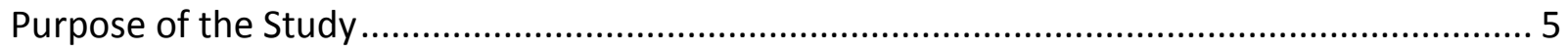

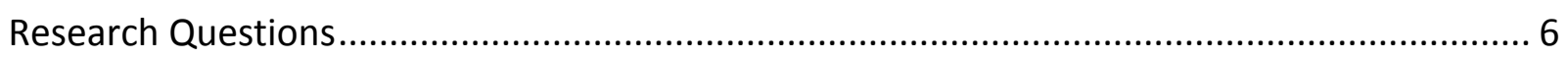

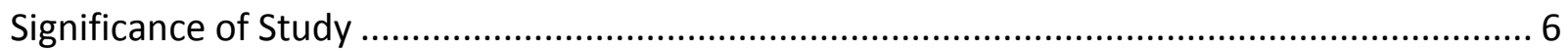

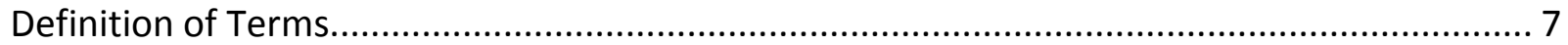

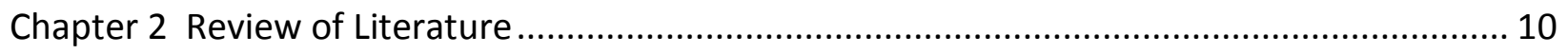

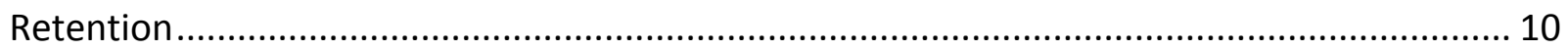

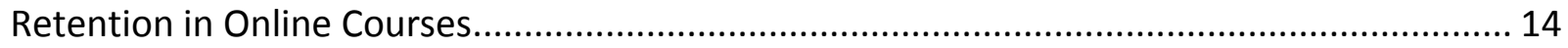

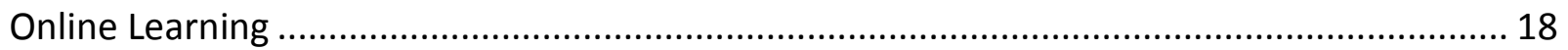

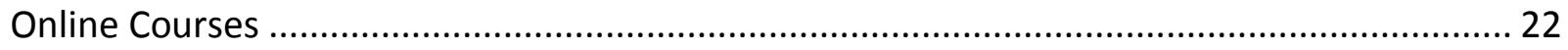

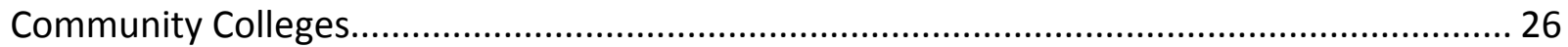

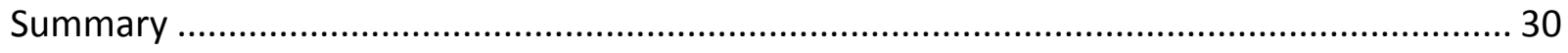

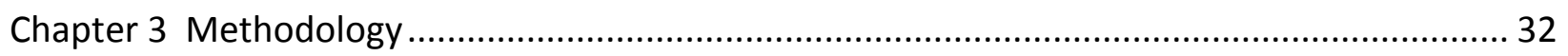

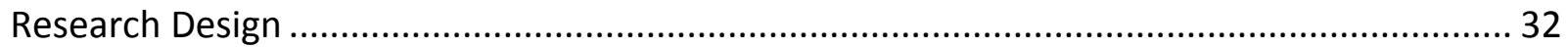

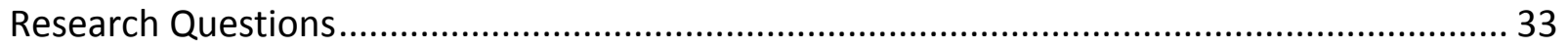

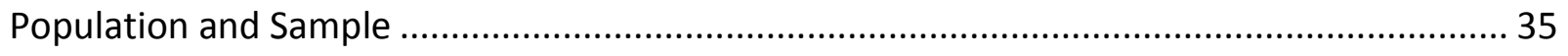

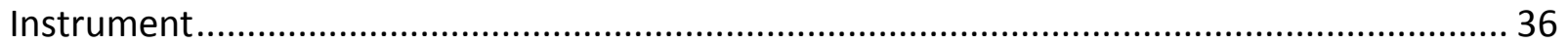




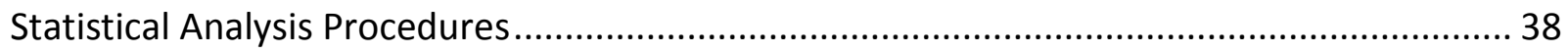

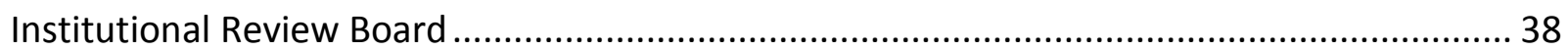

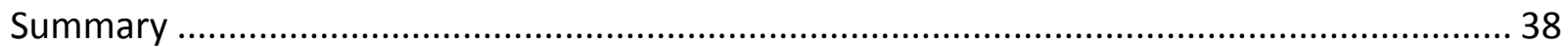

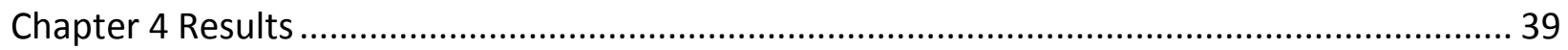

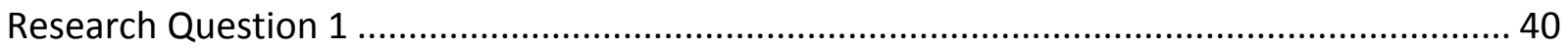

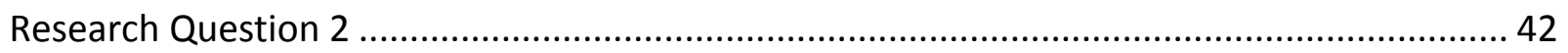

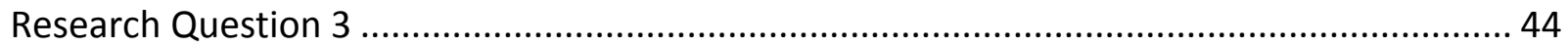

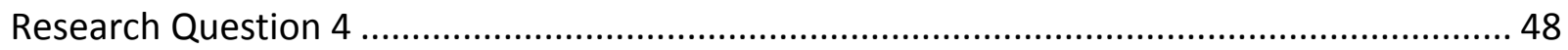

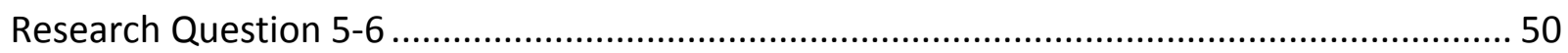

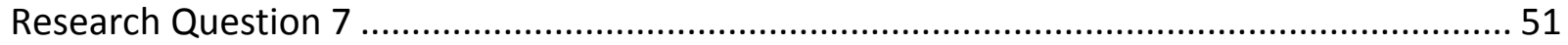

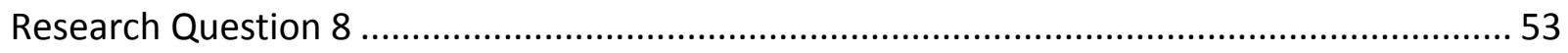

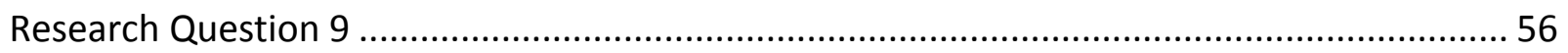

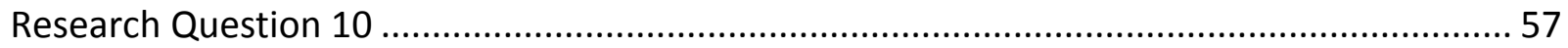

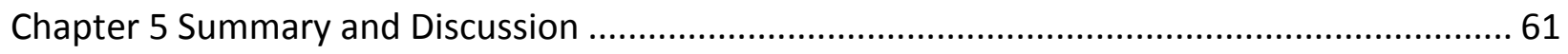

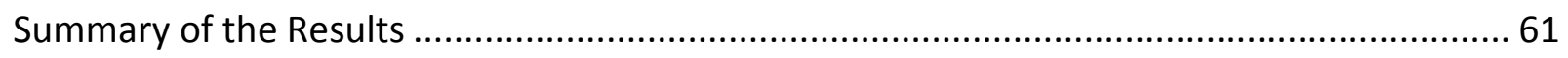

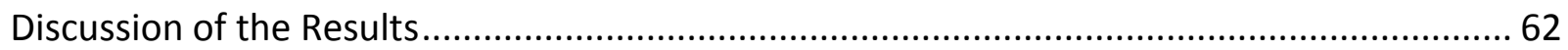

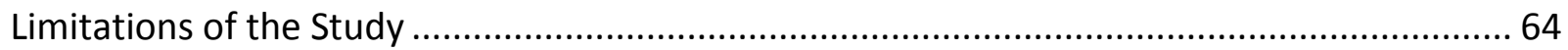

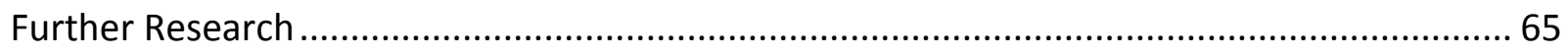

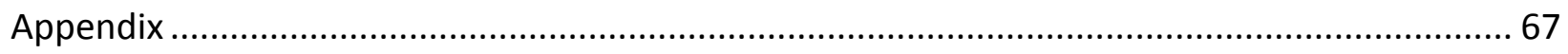

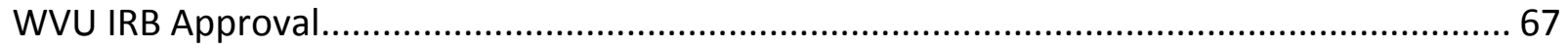

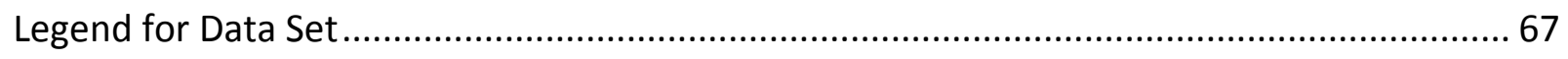

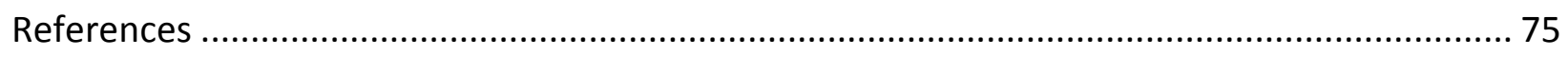




\section{List of Figures and Tables}

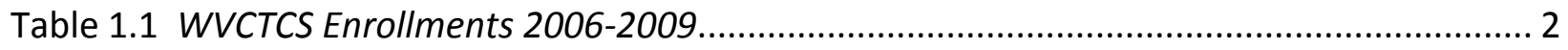

Figure 2.1 Percentage of Students Retained by Race ........................................................... 12

Figure 2.2 Percentages of Institutions with a Designated Retention Coordinator ..................... 16

Table 2.1 Higher Education Enrollments 2002-2009 ........................................................... 20

Figure 2.3 Percentage of online education delivery systems ............................................... 24

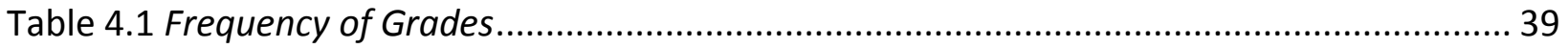

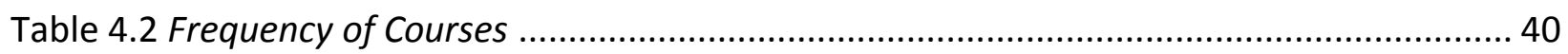

Table 4.3 Withdraw versus Delivery Mode Chi-Square Tests .................................................. 41

Table 4.4 Withdraw versus Delivery Mode Crosstabulation .................................................... 41

Table 4.5 Grade versus Delivery Mode Chi-Square Tests.................................................... 42

Table 4.6 Grade versus Delivery Mode Crosstabulation .......................................................... 43

Table 4.7 Withdraw versus Delivery Method Chi-Square Tests .............................................. 45

Table 4.8 Withdraw versus Delivery Method Crosstabulation ................................................. 45

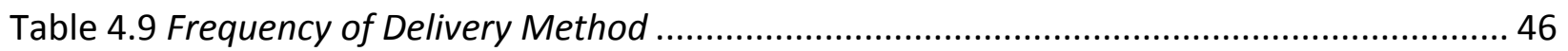

Table 4.10 Institution versus Delivery Method Crosstabulation .................................................47

Table 4.11 Grade versus Delivery Method Chi-Square Tests ................................................... 48

Table 4.12 Grade versus Delivery Method Crosstabulation ..................................................... 49

Table 4.13 Age Range versus Completion Rates in Online Courses Chi-Square Tests ................ 51

Table 4.14 Age Range versus Completion Rates in Online Courses Crosstabulation................... 51

Table 4.15 Age versus Grade in Online Courses Chi-Square Tests ......................................... 53

Table 4.16 Age Range versus Grade in Online Courses Chi-Square Tests ................................. 54 
Table 4.17 Age Range versus Grade in Online Courses Crosstabulation .................................. 54

Table 4.18 Age versus Completion in Hybrid Courses Chi-Square Tests .................................. 56

Table 4.19 Age Range versus Completion in Hybrid Courses Chi-Square Tests .......................... 57

Table 4.20 Age versus Grade in Hybrid Courses Chi-Square Tests ........................................... 58

Table 4.21 Age Range versus Grade in Hybrid Courses Chi-Square Tests................................ 58

Table 4.22 Age Range versus Grade in Hybrid Courses Crosstabulation ..................................... 59 


\section{Chapter 1}

\section{Introduction}

Chapter One provides an overview of this study including the purpose of this study, the statement of the problem, the research questions, and a list of definitions. Chapter Two provides a thorough review of the relevant literature regarding online courses, retention, and applicable theories. Chapter Three provides a conceptual framework for the overall structure of the study and the research methods used. Chapter 4 provides results on data collected and analyzed to answer the Research Questions described in Chapter 3. Chapter 5 provides a summary of the data and discusses the results and recommendations for further research.

Over the past ten years, online enrollment has been growing substantially in higher education institutions, from 1.6 million in 2002 to over 5.6 million in 2009 (Allen \& Seaman, 2007, 2010). This growth in online distance education has generated new research and definitions of successful completion. Meyer (2006) suggests that online learning is accepted as well as face-to-face formats. Studies suggest that the average retention rate for students in distance education courses was $72 \%$ while the retention rate in traditional courses was $78 \%$ (Lakken, Womer, \& Mullins, 2008). Institutions want to retain and attract more online students as overhead costs are much lower than face-to-face courses. In online courses, institutions can also increase limits beyond the physical capacity of rooms. Nevertheless, there is little evidence about how to retain these online students and how to prevent them from withdrawing.

The mission of the Community and Technical College System of West Virginia is to deliver affordable, accessible high quality education and training that advances the economic and social development of West Virginia (WVCTCS, n.d.). The West Virginia Council for 
Community and Technical College Education publishes enrollment numbers for West Virginia Community Colleges. In 2006, there were 17,532 students enrolled in West Virginia community colleges (see Table 1.1). By 2009 , this number increased $23 \%$ to 21,608 (WVHEPC \& WVCTCS, 2008-2010). The growth in online education within West Virginia Community Colleges has affected the drop and withdrawal rates in all classes and has therefore affected the overall enrollment.

Table 1.1

WVCTCS Enrollments 2006-2009

\begin{tabular}{|c|c|c|c|c|}
\hline Institution & 2009 & 2008 & 2007 & 2006 \\
\hline Blue Ridge CTC (CTC Shepherd) & 3198 & 2468 & 2184 & 1955 \\
\hline Bridgemont СTC (СTC at WVU Tech) & 913 & 767 & 747 & 675 \\
\hline Eastern CTC & 639 & 545 & 537 & 784 \\
\hline Kanawha CTC (WVCTC) & 2235 & 1752 & 1643 & 1649 \\
\hline Mountwest СTC (Marshall СTC) & 3083 & 2534 & 2476 & 2579 \\
\hline New River CTC & 2811 & 2666 & 2255 & 1861 \\
\hline WV Northern CC & 3327 & 3069 & 2237 & 2911 \\
\hline Pierpont CTC (Fairmont CTC) & 2783 & 2666 & 2854 & 2803 \\
\hline Southern CTC & 2619 & 2548 & 2272 & 2315 \\
\hline Total WVCTCS Enrollment & 21,608 & 19,015 & 17,205 & 17,532 \\
\hline
\end{tabular}

(WVHEPC \& WVCTCS, 2008-2010).

The number of students enrolled in credit classes in West Virginia Community Colleges has increased $19.8 \%$ since Fall 2005. Over this five-year span from Academic Years 2005-2006 
to 2009-2010, eight institutions have realized increases in enrollment while two have experienced decreases. The largest increase has been $86.4 \%$ at Blue Ridge CTC, and the largest decrease has been 27.2\% at Eastern CTC (WVHEPC \& WVCTCS, 2008-2010). The number of adult students enrolled in credit courses has also increased $21.5 \%$ since Fall 2005 . Over the five year span from 2005-2006 to 2009-2010, eight institutions have realized increases in adult enrollment while two have experienced decreases. The largest increase has been $66 \%$ at Blue Ridge CTC, and the largest decrease has been $12.9 \%$ at Southern CTC (WVHEPC \& WVCTCS, 2008-2010). The State of West Virginia requires all state institutions to report certain aspects of their enrollment each semester and these enrollments have been compared for further analysis.

\section{Problem Statement}

The problem is that withdrawal and completion rates have serious implications for institutions and may prevent the Community and Technical College System from fulfilling its mission. When students do not complete courses it affects the institutions retention and graduation rates as well as affecting the number of courses a student attempts. Many institutions have created special programs and have staff whose primary job responsibility it is to increase student enrollment. Students are enrolling in online courses at a higher rate than face-to-face or hybrid courses, yet, little is known about why these students are not completing these courses. Students may lack expertise in utilizing technology and/or experience frustration with coursework material and the independent nature of online courses.

This problem is not limited to any specific group of students; it is universal to all students in higher education, traditional and non-traditional, full-time and part-time and in any 
given semester. If there is an increased rate of withdrawals, the institution is faced with an increase in non-completers and student departures, as well as a loss of financial aid. Increased withdrawals can affect an institution's retention and completion rates, as well as a student's GPA, their drive to continue in school, their attainment of satisfactory academic progress, and their ability to qualify for continued financial aid. Administrative officials want more students overall and more completers in courses. Instructors want quality students who receive quality instruction. Finally, students want to obtain an education in an efficient and affordable manner.

With a better use of technology and a better understanding of the concepts administrators, faculty, and students can reach their educational goals. Students will acquire critical thinking skills, complete online and face-to-face courses, and graduate with their intended credential. The institution also succeeds because both retention and completion rates will increase.

Institutions want to provide faculty and students with what they desire, but institutions are also obligated to follow federal regulations. Federal regulations require institutions to establish Satisfactory Academic Progress (SAP) standards for all students in eligible degree or certificate programs who wish to receive financial aid. Any student receiving Title IV Financial Aid is required to maintain Satisfactory Academic Progress according to The Compilation of Financial Aid Regulations (34 CFR, through 12/31/95 as published by the Department of Education, section 668.34). Students are required to complete a certain number of credit hours they attempt and to show that they are progressing toward a degree in their program of study. Each student must also maintain a grade point average consistent with the regulations 
governing Satisfactory Academic Progress. Students must satisfy both grade point average and attempted hours' standards for progress toward a degree. If students are dropping and withdrawing from online courses at a higher rate than traditional courses, they will no longer be meeting SAP requirements to receive Federal Financial Aid monies (Federal Student Aid, n.d.). Once students do not meet institutional SAP requirements, they will no longer be eligible for federal financial aid at that institution.

\section{Purpose of the Study}

The purpose of this study is to establish how big the problem is and determine what future research needs to be completed to combat the problem. Hossler (2006) examined multiple studies on online courses and distance education, yet institutions know little about efforts to enhance student persistence and retention or effectively manage students in an online setting.

In one American Federation of Teachers (AFT) study, 42\% of instructors reported higher dropout rates in their online courses than in their traditional courses; more research is needed to determine the accuracy of these numbers (AFT, 2000). Two-year, open enrollment, public institutions have the lowest retention rates due to the diversity of students being admitted (Beal \& Noel, 1979; Cowart, 1987). Community college students come from all ethnicities, economic backgrounds, and social status backgrounds. Attrition studies have shown that students at community colleges often stop or drop out due to the pressures of meeting the challenges of everyday life. The current definitions of the student at risk describe the majority of the students in American Community Colleges (Perez, 1998). The evidence to date suggests 
that most institutions have not developed retention programs for online education to assist with these at risk students (Hossler, 2006).

\section{Research Questions}

RQ1: Is there a difference in completion rates between online, hybrid, and traditional courses? RQ2: Is there a difference in grade achieved between online, hybrid, and traditional courses? RQ3: Is there a difference in completion rates between delivery method used in online courses? RQ4: Is there a difference in grade achieved between delivery method used in online courses? RQ5: Is there an interaction between delivery method and degree of non-traditional delivery on completion rates?

RQ6: Is there an interaction between delivery method and degree of non-traditional delivery on grade achieved?

RQ7: Is there a significant difference in age and completion rate in an online course? RQ8: Is there a significant difference in age and grade achieved in an online course? RQ9: Is there a significant difference in age and completion rate in a hybrid course? RQ10: Is there a significant difference in age and grade achieved in a hybrid course?

\section{Significance of Study}

This study involves one of the most important factors in education; providing high quality education at an economic cost to the institution. If students are withdrawing or not completing courses at a higher rate, this can have a drastic effect on institutions ability to provide students with federal financial aid. The majority of students at Community and Technical Colleges in West Virginia receive some type of federal financial aid. If students are not completing courses at a designated rate, the student can lose their federal financial aid at 
that institution. Once a student is no longer receiving these monies, they are likely to leave the institution. Once students leave an institution, this affects that institutions graduation and retention number; which can affect their state funding.

Online enrollments have been increasing steadily from 1.6 million in 2002 to over 5.6 million in 2009 (Allen \& Seaman, 2010). Online education has promised to generate growth in education by reducing costs, improving cost-efficiencies, and offering mass communication (Meyer, 2006). With this rapid increase in enrollments, research on student persistence in online courses has not kept pace.

\section{Definition of Terms}

Asynchronous learning is commonly facilitated by media such as e-mail and discussion boards even when participants cannot be online at the same time. Asynchronous online education makes it possible for learners to log on to an online education environment at any time and download documents or send messages to teachers or peers (Hrastinski, 2008).

Chi Square Test is a test statistic that is for categorical data. It is used as a test of independence (Vogt \& Johnson, 2011).

Community college is defined as an institution in Canada or the United States and is a nonresidential college usually supported by the government offering two-year courses and awarding associate degrees (Encarta Dictionary, 2009).

Completion rate is if a student completes a course and does not withdraw or drop the course before the completion of the course (Encarta Dictionary, 2009). 
Delivery method is the primary method of delivery in a course (Internet Asynchronous and Interactive Video Courses).

Degree non-traditional delivery method in a course is the extent to which a course is offered where the learner and instructor are not in the same physical location (100\% to $80 \%$ non-traditional delivery, $79 \%$ to $50 \%$ non-traditional delivery, and less than $50 \%$ nontraditional delivery).

Distance education describes courses in which nearly all of the interactions between teacher and student take place in two separate physical locations (AFT, 2000).

Face- to- face education is teaching and learning in which a significant component requires the presence of both learner and instructor in the same physical space at the same time (Ogunleye, 2010). These are also referred to as traditional courses or live courses.

Grade achieved is a letter representing the students achievement in a course, typically defined as $A, B, C, D, F$ (Encarta Dictionary, 2009).

Hybrid or blended courses include those in which $50 \%$ to $79 \%$ of the course content is delivered online and blends online with face-to-face delivery (Allen \& Seaman, 2007).

Integrated Postsecondary Education Data System (IPEDS) is a system of interrelated surveys conducted annually by the U.S. Department's National Center for Education Statistics (NCES). IPEDS gathers information from every college, university, and technical and vocational institution that participates in the federal student financial aid programs (About IPEDS, n.d.).

Online Course is when instructor communication, course materials, and assignments are posted to a secure website where the instructor and students converse online. Some common 
programs that colleges use to deliver online instruction include WebCT and Blackboard. These courses deliver $80 \%$ to $100 \%$ of the course content online and typically have no face-to-face meetings (Allen \& Seaman, 2007).

Retention is a measure of the rate at which students persist in their educational program at an institution, typically expressed as a percentage and based on whether a student remains enrolled from fall semester to the following fall semester (IPEDS Glossary, n.d.).

Synchronous learning is commonly supported by media such as videoconferencing and chat; learners and teachers are online at the same time. Synchronous online education can reduce frustration by allowing students to ask and answer questions in real time (Hrastinski, 2008).

Traditional course is a course with no online technology used in which all content is delivered in writing or oral form (Allen \& Seaman, 2007). This term is also used to describe teaching and learning situations in which the significant components require the presence of both learner and instructor in the same place at the same time (Ogunleye, 2010). A traditional course is often referred to as face-to-face course or a live course.

Traditional student is somebody who studies at a school, college, or university (Encarta Dictionary, 2009) and is age 24 or younger, even if the student did not enter college immediately after high school.

Withdrawal (course) is removal of oneself from the course as an active participant (Encarta Dictionary, 2009). 


\section{Chapter 2}

\section{Review of Literature}

Online courses provide access to students who are not able to attend (or choose not to attend) a traditional face-to-face course; this includes working adults and single parents (Githens et al., 2010). However, despite the quantity of students who express interest in taking an online class, the environment is not for everyone (Gibbs, 1998). Distance education requires more self-discipline, self-motivation, self-regulation, and less reliance on other students (Lei \& Gupta, 2010). Despite all of the studies of online courses and distance education, institutions know little about efforts to enhance student persistence and retention or how to manage them in an online setting (Hossler, 2006).

\section{Retention}

Retention is a measure of the rate at which students persist in their educational program at an institution, typically expressed as a percentage (IPEDS Glossary, n.d.). Students depart from education for a variety of reasons that are unique to each student but can be for personal reasons or reasons related to the institution or courses. Institutions cannot recover or retain the students who may need to depart for personal reasons, but they can address the reasons that are related to the institution or courses in an attempt to retain those students (Hossler, 2006). In one study, $42 \%$ of instructors reported higher dropout rates in their online courses than in their traditional courses; more research is needed to determine the accuracy of these numbers (AFT, 2000).

Change is stressful and difficult for many students, and this can affect their decision to continue in a program of higher education (Floyd, 2003). The factors that cause students to 
drop out are complex and multi-dimensional. Cabnera, Nora, \& Castaneda (1993) suggested that there are many non-intellectual factors that play a role in retention such as family approval and environmental factors, which directly or indirectly affect a decision to drop out. Background and education variables can predict retention and academic performance (Ronco \& Cahill, 2004). High school GPA, reading textbooks, and expecting to participate in clubs and organizations at the institution all have positive effects on retention (Miller \& Herreid, 2008; Miller, Tyree, Riegier, \& Herreid 2010). Mentoring programs also show an increase in student persistence (Miller \& Tyree, 2009). Research has also shown that students responded better to outreach from a person with whom they had a natural connection rather than what seemed like a random call from an institutional staff member (Miller et al., 2010). The expectation to work off campus has a negative effect on retention in higher education (Miller \& Herreid, 2008; Miller et al., 2010). Among students entering college in the fall semesters of 1997-2001, those not retuning for the spring semester were more likely to have had half of their initial courses taught by a part-time instructor (Ronco \& Cahilll, 2004).

Chen \& DesJardins (2010) studied the 1995-1996 cohort of students who had dropped out of higher education (Figure 2.1) and found that 30\% were Black or African American, $29 \%$ were Hispanics, and $18.8 \%$ were White or Caucasian. In the $1989-1990$ cohort, $27.4 \%$ were Black or African American, 29.4\% were Hispanics, and 25\% were White or Caucasian. During the $1998-1999$ academic year, $46.7 \%$ of students completed degrees at four-year public institutions, and $38.7 \%$ of students completed degrees at two-year public institutions (Zhai \& Newcomb, 2000). 
Figure 2.1

Percentage of Students Retained by Race

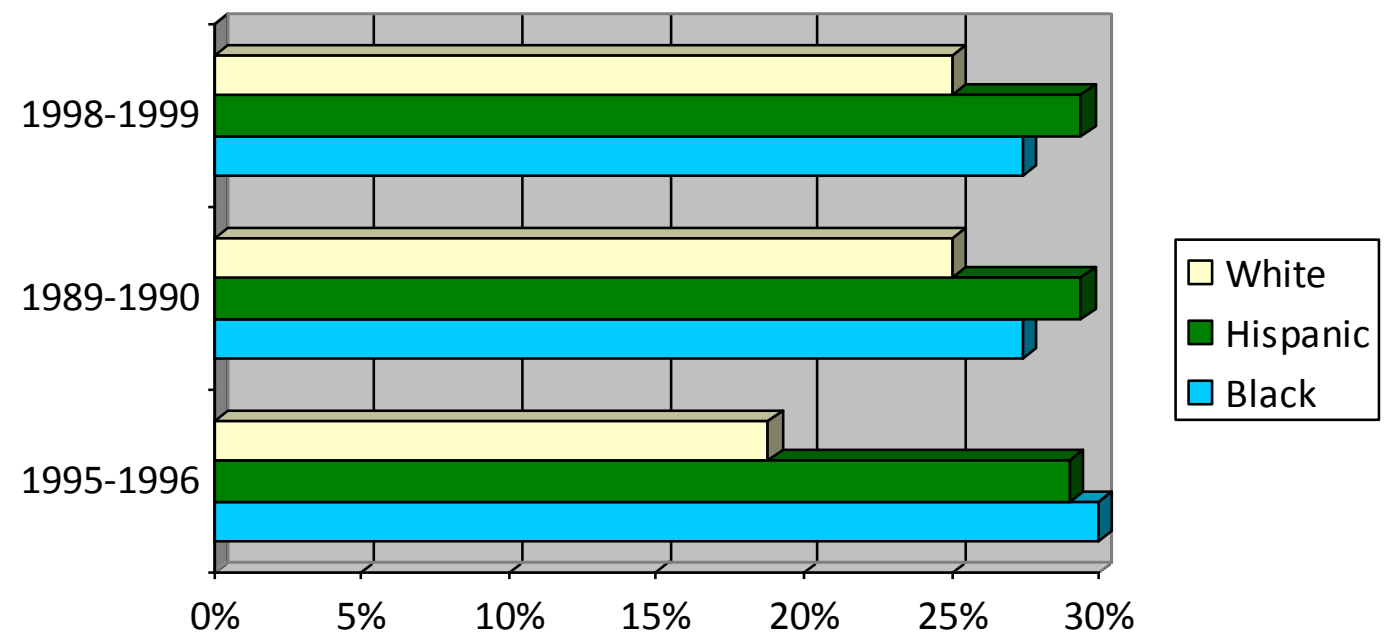

(Chen \& DesJardins, 2010; Zhai \& Newcomb, 2000).

The federal Integrated Post-Secondary Education Data System (IPEDS) found that in $2003-2008,30 \%$ of first year college students who failed to return to campus for a second year accounted for $\$ 6.2$ billion in state appropriations for the institution and more than $\$ 1.4$ billion in student grants (Lederman, 2010; Schneider, 2010).

Students make decisions about matriculation based upon complex factors; each of these factors (e.g. communication with instructors, personal goals) is unique to each student. Multiple factors typically combine to predict retention; therefore, institutions should focus on the aspects of retention that they can affect to ensure that time and resources are not wasted (Miller \& Herreid, 2008). Robbins, Allen, Casillas, Peterson, and Le (2006) identified ten items that enhance retention qualities in students; these include academic discipline, academic self confidence, communication skills, commitment to college, emotional control, general determination, goal striving, social activity, social connection, and study skills. Academic 
discipline refers to the amount of effort a student puts into schoolwork and the degree to which they see themselves as hardworking and conscientious. Academic self-confidence refers to the extent in which the student believes they can perform well in classes. Communication skills refer to how attentive a student is to others' feelings and how flexible they are in resolving conflicts. Students who are committed to college will battle odds to stay in college and complete their desired degree. Emotional control is how a student responds to strong feelings and how they manage those feelings. General determination refers to how much a student strives to follow through on commitments and obligations. Goal striving is the strength of a student's effort to achieve objectives and goals. Social activity is how comfortable a student feels meeting and interacting with other people. Social connection is a student's feeling of connection and involvement with the institution or community. Lastly, study skills are the extent to which a student believes they know how to assess an academic problem, organize a solution, and successfully complete academic assignments.

Academic deficiency is one of the major reasons students depart from higher education (Zhai \& Newcomb, 2000). The stronger a student's academic performance, the better chance the institution has at retraining the student (Luo, Williams, \& Vieweg, 2007). Students can have trouble with resources such as internet access, networked computers, and printing facilities, which can retard their progress and interest (Ogunleye, 2010). When institutions offer support services, all students, not just first time freshmen, should be included in these efforts, as this will assist in increasing retention (Hutt, Bray, Jones, Leach, \& Ward, 2010).

Special attention should be given to transfer students with lower GPA's to assist in their retention numbers. A transfer student's age has a significant negative impact on retention; the 
younger the student, the more likely they are to be retained (Zhai \& Newcomb, 2000). Transfer credit hours also make a difference in graduation and retention rates. Transfer students who transferred less than 32 credits are less likely to graduate than native students are; while transfer students with 32 or more credits graduate at a significantly higher rate than native students (Gao, Hughes, O’Rear, \& Fendley, 2002). Transfer credit hours and student residency status have an impact on retention, and students with more than 32 transfer credits are more likely to be retained the following year (Luo et al., 2007).

Residency is another factor that highly affects retention; out-of -state students are less likely to be retained than in-state students. Generally the difference in in-state and out-of-state tuition has a dramatic financial impact on students. Institutional scholarships can have a positive impact on retention of out-of-state students. Special attention and support must be provided to students transferring with lower transfer GPAs and fewer earned credit hours. Academic performance, as indicated by GPA and earned credit hours, is one of the most significant factors influencing a student's decision to persist (Luo et al. 2007). Student retention is a mix of complex factors that may or may not be controlled by the institution. If institutions are aware of those factors and attempt to address issues that cause students to depart, they can effectively raise their retention rates. Retention in online courses poses additional factors to consider.

\section{Retention in Online Courses}

Student persistence often affects courses offered at a distance, partially due to the lack of physical contact with students and the instructor, self-discipline, or good study habits. Students cited numerous reasons for enrolling in online courses, including the flexibility and 
convenience. Students complete coursework at a time and place that better accommodates each individual student. When students delay completion of assignments and participation in class activities, they consequently fall behind and have no other recourse than to withdraw (Gibbs, 1998). Lei and Gupta (2010) cite various reasons why online courses are not always successful; these include lack of face-to-face interaction with the instructor and classmates, high dropout rates, and lack of accountability. When students drop or withdraw from courses, it has a negative effect on the institution's retention and graduation rates.

Increased numbers of students are leaving college prior to earning a degree compared to the overall population (Zhai \& Newcomb, 2000). In 1979, the retention rates for all types of institutions showed that two-thirds of entering freshmen returned as sophomores. During this same time, $70 \%$ of two-year public institutions (see Figure 2.2 ) and $48 \%$ of four-year institutions did not have a staff member whose primary job duty was to focus on retention (Beal \& Noel, 1979). In 1987, the percentage of all institutions that did not have a staff member whose primary job duty was to focus on retention declined to 56\% (Cowart, 1987). By 2004, 48.3\% of institutions did not have a staff member whose primary job duty was to focus on retention. Also by $2004,47.2 \%$ of institutions reported an improvement goal for the retention of students (Habley \& McClanahan, 2004). By 2010, only $40 \%$ of community colleges did not have a staff member whose primary job duty was to focus on retention (Habley, Valiga, McClanahan, \& Burkum, 2010). Nationally about $60 \%$ of students graduated from four-year institutions within six years (Schneider, 2010). 
Figure 2.2

Percentages of Institutions with a Designated Retention Coordinator

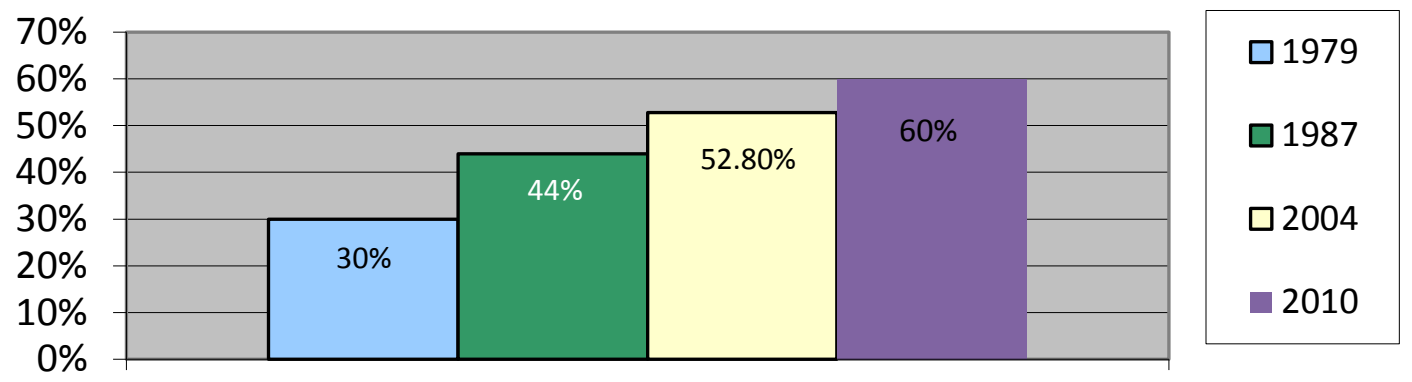

(Beal \& Noel, 1979; Habley \& McClanshan, 2004; Habley et al., 2010).

Highly selective, four-year, nonsectarian institutions have the highest retention rates.

Conversely, two-year, open enrollment, public institutions have the lowest retention rates (Beal \& Noel, 1979; Cowart, 1987). In 2010, the retention rate for community colleges was 56\% (Habley et al., 2010). Clemetsen \& Balazer (2008) estimate that one third of students transfer at some point from a community college to a university. Attrition studies have shown that students at community colleges often stop or drop out due to the pressures of meeting the challenges of everyday life. The current definitions of the student at risk describe the majority of the students in American Community Colleges (Perez, 1998).

Tinto's retention model. Perhaps the most interesting finding is the small number of studies focusing on retention in online courses. The evidence to date suggests that most institutions have not developed a large number of retention programs for online education (Hossler, 2006).

Tinto's retention model (1975) proposes a predictive model based upon principles of the students' level of academic and social integration and how it affects retention (Miller, 2007). 
Tinto views student departure as a longitudinal process that occurs because of the meanings that the individual student describes to their interactions with the formal and informal dimensions of the institution. These interactions occur between the student and the academic and social systems of the institution. Tinto suggests that various individual characteristics such as family background, individual attributes, and precollege schooling experiences directly influence student retention as well as their commitment to graduation. Academic integration has both structural integration (institution meeting standards) and normative integration (individuals' identification with beliefs, values, and norms). Social integration occurs in conjunction with the community of the institution and typically projects itself within certain subcultures (Braxton, Hirschy, \& McClendon, 2004). Tinto's key structure is the greater the amount of integration, the more likely that a student will persist until graduation. Tinto's theory was revised in 1993 and identified the major sources of student departure as academic difficulties. These include the student's inability to reduce their goals, and the student's failure to remain incorporated within the institution (Braxton et al., 2004).

The majority of community and technical colleges in West Virginia do not provide dormitory rooms to students, as a large percentage of students enrolled are commuter students. Tinto also suggests that commuter colleges lack well-defined and well-structured social communities in which students can establish memberships. The more a student perceives that the institution is committed to the welfare of its students, the lower the likelihood the student will drop out or withdraw. Commuter students also typically experience more conflicts among their obligations to family, work, and college. Tinto proposes that to reduce commuter student's departure is to reduce cost; the lower the costs of college 
attendance incurred by students, the greater their likelihood of persisting in college (Braxton et al., 2004).

Related theories. The Student Attrition Model emphasizes the role of the student to persist and focuses on attitudes, institutional fit, and external factors. External factors include factors such as the family approval of the institutional choice, friends' encouragement to continue enrollment, financial attitudes, and perceptions about the opportunities to transfer to other institutions and their impact on withdrawal decisions (Cabnera et al., 1993).

Schlossberg's Transition Model (1995) provides theoretical insights into factors related to a transfer student's transition experience from college to college. The transition model of Schlossberg supports the facilitation of coping as well as appropriate strategies for assisting individuals experiencing change and transition (Luo et al., 2007).

\section{Online Learning}

During the 2009-2010 academic years, one in four students took at least one online course at an institution of higher education in the United States (Allen \& Seaman, 2010). Online education is one type of distance education course and refers to the use of technology-based instruction in which student and instructor can be in two separate physical locations during the course (Githens et al., 2010; Lei \& Gupta, 2010). Distance education is not a new concept. The idea of reducing costs and increasing enrollment for courses in which the student and instructor are in separate physical locations has taken the form of correspondence courses, videotaped courses, and independent study courses for many years. However, distance education through web-based learning is a relatively new concept in education (Lei \& Gupta, 2010). 
The concept of distance education has evolved over time but has been present in one form or another for over 200 years. Correspondence study began as early as the 1800's. In 1833, a Swedish newspaper offered a composition course at a distance. By 1840, England's Isaac Putman established the Penny Post to offer shorthand courses via correspondence, which later became Sir Isaac Pitman's Correspondence College; these types of correspondence courses continued for hundreds of years (Tracey \& Richey, 2005). New York formed Empire State College in 1971 to accommodate students who lived in areas too remote for commuting to a campus (Cohen, 1998). Over the years, there have been various types of distance education, which have included satellite discussion, video conferencing, cable, audio tapes, computer systems, fax, correspondence courses, home study, and independent study (Floyd, 2003).

Since the late 1990s, online enrollments have been growing substantially faster than overall higher education enrollments (Allen \& Seaman, 2007). During the 1997-1998, academic years, there were over 1.6 million students enrolled in online courses (AFT, 2000; Orellana, 2006). Among all US higher education students in fall 2002, $11 \%$ took at least one online course (Allen \& Seaman, 2003). By fall 2003, enrollments in online courses totaled 1.9 million, having grown 20\% from fall 2002 (Meyer, 2006). Almost 3.5 million students, $22 \%$ of the total student enrollment, were taking at least one online course during the fall 2006 term. This is nearly a $10 \%$ increase over the previous year (Allen \& Seaman, 2007). For the 2006-2007 academic years, two and four year institutions reported an estimated 12.2 million enrollments in college level credit granting online courses (Parsad \& Lewis, 2008). By fall 2007, the number increased to 3.9 million students taking at least one online course (Lei \& Gupta, 2010). Over 4.6 million 
students were taking at least one online course during the Fall 2008 semester. This is a whopping 17\% increase over the Fall 2007 semester (Allen \& Seaman, 2010). Online enrollments increased from 1.6 million in 2002 to 5.6 million in 2009 (see Table 2.1). Table 2.1

Higher Education Enrollments 2002-2009

\begin{tabular}{llll}
\hline Year & \% increase over previous year & \# of online enrollment & overall enrollment \\
\hline 2002 & $19.8 \%$ & $1,600,000$ & $16,612,000$ \\
2003 & $22.9 \%$ & $1,980,000$ & $16,911,000$ \\
2004 & $18.2 \%$ & $2,300,000$ & $17,272,000$ \\
2005 & Not available & Not available & $17,487,000$ \\
2006 & $10 \%$ & $3,500,000$ & $17,759,000$ \\
2007 & $12 \%$ & $3,900,000$ & $18,248,000$ \\
2008 & $17 \%$ & $4,600,000$ & Not available \\
2009 & $21 \%$ & $5,600,000$ & Not available \\
\hline
\end{tabular}

(Allen \& Seaman, 2010; NCES, 2005; Snyder, Dillow, \& Hoffman, 2008).

From 1995-1998, the use of online course content grew from 22\% to 60\% (AFT, 2000). Between 1997 and 1998, the growth of online distance learning programs was well over 70\% (Benson, Johnson, Duncan, Shinkareva, Taylor, \& Tod Treat, 2008). By the 2000-2001 academic year, $56 \%(2,320)$ of all Title IV eligible schools offered some type of distance education course, and $19 \%$ of these institutions had degree or certificate programs that were offered entirely online (Waits \& Lewis, 2003). During the Fall 2002 semester, 13\% of students took at least one online course at their institutions. In the $2002-2003$ academic years, $97 \%$ of public institutions 
offered at least one online or blended course, and $49 \%$ offered online degree programs (Allen \& Seaman, 2003). Even more staggering is the fact that over one-third of 578,000 students took all of their courses online in 2002-2003 (Allen \& Seaman, 2003). Enrollments in $100 \%$ online programs totaled 937,000 students in 2004 or $7 \%$ of the total student enrollment in degreegranting institutions. More than $90 \%$ of public institutions provided some sort of distance learning and enrolled 3,077,000 students in 2004 (Meyer, 2006). Online enrollments increased 18\% from Fall 2005 to Fall 2006 (Lakken et al., 2008). By the $2006-2007$ academic year, 66\% of all title IV eligible schools offered some type of distance education course, and $32 \%$ of these institutions had degree or certificate programs that were offered entirely online (Parsad \& Lewis, 2008). This was a 15\% increase in online enrollments from Fall 2006 to Fall 2007. Of these enrollments $60 \%$ of students were female, $40 \%$ were male students, $48 \%$ were traditional age (18-25), and 52\% were nontraditional students over age 26 (Lakken et al., 2008). The Sloan Consortium reports that as of 2009 , more than 4.3 million U.S. college students had taken at least one fully online class (Schaeffer, 2010). Institutions reported that in $2009,76.3 \%$ of institutions offered an online education program (Githens et al, 2010). In 2009, 66\% of institutions reported an increased demand for new online courses and programs with $73 \%$ showing an increase in existing courses and programs (Allen \& Seaman, 2010). During the spring of $2009,2.5 \%$ of institutions reported offering an online program specific to "green" programs online (Githens \& Sauer, 2010).

There is an increasing number of students who rely on the access and convenience of online courses to develop job skills, achieve economic mobility, and increase their contributions to society (Githens et al., 2010). Many institutions use online education to enhance offerings 
and attract more students (Stone, 2007). Online courses can range from short-term training workshops to undergraduate and graduate programs for academic credit (AFT, 2000). Online education has promised to generate growth in education by reducing costs, improving costefficiencies, and offering mass communication (Meyer, 2006). The most significant technological development with online education is that the former constraint of time and space is largely removed by networking capabilities (Lei \& Gupta, 2010).

The swift expansion of online education and enrollments has generated an interest in defining online learning (Meyer, 2002). Distance education describes courses in which nearly all of the interactions between teacher and student take place in two separate physical locations (AFT, 2000).

Online learning is a term that constitutes just one part of technology learning. It describes learning via the internet, intranet, and extranet, which involves such activities as animations, simulations, audio and video sequence, peer and extranet groups, online mentoring, and links to materials on an intranet or the web (Ogunleye, 2010). Online courses are attached to or available through a central computer or computer network (Encarta Dictionary, 2009). Instructor communication, course materials, and assignments are posted to a secure website where the instructor and students converse online. Some common programs that colleges use to deliver online instruction include WebCT and Blackboard.

\section{Online Courses}

Online courses are defined as those in which $80 \%$ to $100 \%$ of the course content is delivered online and typically have no face-to-face meetings (Allen \& Seaman, 2007). When course content is delivered online $50-79 \%$ of the time, it is considered a hybrid or blended 
course. These courses blend online with face-to-face delivery (Allen \& Seaman, 2007). Web facilitated courses are defined as those in which $1 \%$ to $29 \%$ of the content is delivered online. These courses use web-based technology to facilitate what is essentially a face-to-face course. These courses use a course management system or web pages to post the syllabus and assignments (Allen \& Seaman, 2007).

Online courses can also be synchronous or asynchronous. Asynchronous courses are cited as the most common type of instructional delivery for distance education courses (Parsad \& Lewis, 2008). Asynchronous learning activities are not simultaneous or real time. They include items such as email and discussion boards. Students can log on and participate at any time regardless of when the instructor is online; this allows student with nontraditional shifts to participate in coursework they otherwise may not be able to complete. Synchronous learning is simultaneous or real time and includes items such as computer conferencing or chat rooms (Ogunleye, 2010). In synchronous learning, faculty and students interact at a designated time, so all participants must be logged onto the web course content page at the exact same day and time (similar to a traditional classroom day, time, and location). There are various software packages that institutions use to deliver their online courses; Figure 2.3 reviews the percentages of programs used. 
Figure 2.3

Percentage of online education delivery systems

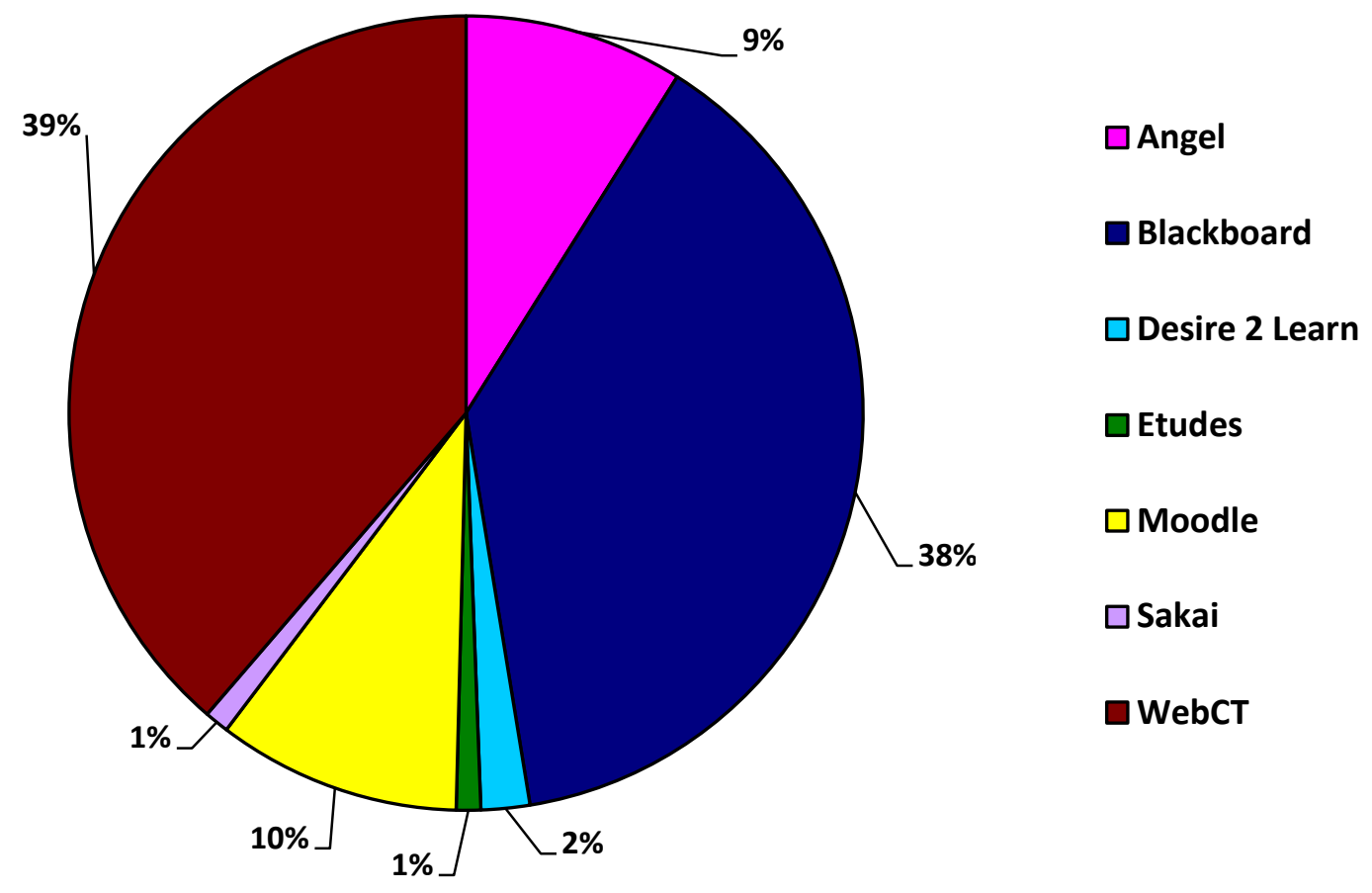

(Lakken et al., 2008).

There is evidence that online formats support learning as effectively as traditional faceto-face and even enhance learning for many students (Meyer, 2006). Online environments can help students gain a more reflective insight on controversial social issues such as cultural diversity and discrimination due to the potential anonymity. A web-based classroom is a different social environment from a traditional classroom, and as such, it requires different actions from students (Jackson, 2005). Online learning can also become a way of fulfilling social goals, such as the pursuit of a degree. This type of learning can provide individuals with educational and economic opportunities that may not have been possible from traditional learning methods (Githens et al., 2010). Although there are no definite answers to these questions, it does emphasize that critical emotional reflexivity can take a variety of forms in the 
online format. A variety of students can utilize the opportunities online communication can offer to enrich their critical reflectivity on difficult issues (Zembylas, 2008). There are several complex issues involved in the nature of online discussions including, but not limited to, the trust between instructor and students and the trust among students. This can affect the quality of online components, as there may be a reluctance of students to share personal content online (Zembylas, 2008).

The most common factors contributing to an increase in online education are student demand for flexible schedules, access to students who may not otherwise have access, availability of more courses, and an increase in student enrollment (Parasad \& Lewis, 2008). Findings indicate that even through the actual class sizes of online courses are not related to their interactive quality, there is a belief that smaller class sizes achieve higher interactive levels in an online setting (Orellana, 2006). A web-based form of instruction allows instructors to reach a much larger audience and encourages more flexibility with students' schedules. Online courses require students to meet specific deadlines for posting course assignments or posting in an online discussion forum (Lei \& Gupta, 2010). Online education instructors are more dependent on the quality of their learning materials and services than are instructors in a traditional classroom setting (Hirumi, 2005). In one study, both instructor and student indicated that web-based contact should be organized in a manner that is easy to follow (Hardy \& Bower, 2004).

As noted previously, online courses can provide more access to students who may not be able to attend a traditional on-campus lecture course (Githens et al., 2010). Greater numbers of students are taking an interest in online class, but not everyone is suited for the 
online environment (Gibbs, 1998). Distance education requires more self-discipline, selfmotivation, self-regulation, and less reliance on other students (Lei \& Gupta, 2010). Champions of online education argue that more students are served by online course offerings than by traditionally delivered courses (Floyd, 2003).

Some students feel isolated when they have issues such as computer and software problems because they have not experienced the face-to-face interaction with the instructor and other students. This inability to see facial expressions and non-verbal reactions is considered a hindrance to communication (Gibbs, 1998). Effective communication strategies for online courses include graphics, sound, video, human interfaces, email, discussion boards, conferencing, and chats (Ogunleye, 2010). Students also expressed concerns with information overload and time requirements of the course (Gibbs, 1998). Students rated courses favorable that have all course documents (syllabus, lecture notes, handouts, assignment sheets, interactive demonstrations, audio lectures, and video lectures) easily accessible on the course site (Lei \& Gupta, 2010).

Several common challenges for students include documents not being received by instructor, instructor's inability to open student documents, and challenges due to equipment malfunction (Lei \& Gupta, 2010). These challenges, as well as others, may be resolved through effective communication between instructor and students.

\section{Community Colleges}

A community college is defined as an institution in Canada or the United States, which is a nonresidential college usually supported by the government and offering two-year courses while awarding associate degrees (Encarta Dictionary, 2009). Joliet Junior College in Illinois, 
established in 1901, is the oldest existing public two-year college. Community colleges became a national network in the 1960s with the opening of 457 public community colleges. By 1998, there were over 16,000 in existence (AACC, 2010b). Community colleges serve close to half of all undergraduate students in the United States. This number was more than 6.5 million students in Fall 2005 (AACC, 2010c).

In the 1996-1997 academic year, 14 million students attended community colleges; this included 9.3 million in credit courses and 5 million in non-credit courses (AACC, 2010b). During the Fall 2007 semester alone, 11.8 million students attended community colleges; this included 6.8 million in credit courses and 5 million in non-credit courses. In the United States, $90 \%$ of the population lives within 25 miles of a community college (AACC, 2010a). The majority of healthcare providers are educated at community colleges. This includes $59 \%$ of the new nurses entering the workforce. Close to 1 million international students attend community colleges; this is approximately $39 \%$ of all international students in the United States. Of all community college students, $40 \%$ are full time students, and $60 \%$ are part time students. More than $59 \%$ of community college students use some type of financial aid to assist them in paying for their education (AACC, 2010b). About $75 \%$ of first year students at community colleges need at least one remedial course (Kolowich, 2010).

Clemetsen \& Balazer (2008) indicate that nearly $40 \%$ of students who receive a bachelor degree transfer some credits from a community college. According to the American Association of Community Colleges (AACC), $46 \%$ of all undergraduates are enrolled in a community college based on January 2007 data from the College Board and the U.S. Department of Education 
(Clemetsen \& Balazer, 2008). A two-year degree can increase an average worker's income by $20 \%$ to $30 \%$ when compared to high school graduates (Githens et al., 2010).

Two-year, associate degree institutions have had the highest growth rate and account for over one half of the secondary education enrollment from 2001 to 2006 (Allen \& Seaman, 2007). More than $60 \%$ of jobs will require an associate degree or technical certificate. Less than $20 \%$ of all jobs require an individual to possess a baccalaureate degree or higher (Stone, 2007). Many factors have affected the 2009 institutional budgets due to the economic downturn; $50 \%$ of budgets have decreased, $25 \%$ of budgets have increased, and $25 \%$ reported no change. During the same time, $54 \%$ of institutions report that there has been an increased demand for online courses (Allen \& Seaman, 2010). Online courses require fewer resources from the institution than face-to-face courses; therefore, it is cheaper for institutions to offer online courses than traditional courses. While an analysis of online education is relevant to the entire field of higher education, it is especially important for the community college whose mission is to provide higher education to all students (Cox, 2005; Floyd, 2003).

Community colleges are diverse institutions that serve a wide variety of needs. These include students who attend to update skills for a current job, pursue an associate degree or certificate, transfer to a four-year institution, or expand their personal interests (AACC, 2010c). Community colleges provide more flexibility, are generally low cost, are job specific, and have high quality opportunities for students (Githens et al., 2010).

Community colleges are open access institutions; they cannot increase their retention or graduation rates by being more selective in admissions. When compared with students at baccalaureate institutions, community college students have more characteristics that might 
compromise their ability to succeed in college, such as lower test scores, delayed enrollment after high school, part-time attendance, and interruption of their college studies. Community colleges assert that the cohort of first-time, full -time freshmen students is uncharacteristic of community college students because the majority attend part time for some if not all of their enrollment. There is the potential for under reporting of transfer rates for community colleges because many institutions do not know what happens to their students once they leave. Transfer rate is the number of cohort students who transfer to another institution within $150 \%$ of the expected graduation time. The Fall 1999 cohort of community college students showed that $22.3 \%$ of students earned their degree at their first institution within $150 \%$ of the expected time (Bailey, Jenkins, \& Leinbach, 2005). Supporters say that currently two-year colleges' retention data fails to account for the many students who transfer to four-year colleges without obtaining an associate degree (Epstein, 2010).

While an analysis of online education is relevant to the entire field of higher education, it is important for the community college whose mission is to provide higher education to all students (Cox, 2005). Online degrees and certificates allow community colleges in all demographic areas to participate in retraining the workforce and developing occupational skills (Githens \& Sauer, 2010). In addition to significant increases in the use of technology, community colleges have seen a phenomenal growth in distance education programs (Floyd, 2003).

Although online education permeates most community colleges, some offer more online programs (Githens et al., 2010). Students at $41 \%$ of public community colleges can earn a degree entirely online, and $92 \%$ of all community colleges offer at least one internet based 
course (AACC, 2010a, Githens et al., 2010). As of 1994, $80 \%$ of community colleges offered some form of distance education (Floyd, 2003). In 2000-2001, public two-year institutions had the greatest number of enrollments in distance education with $1,472,000$ out of $3,077,000$ or $48 \%$ of the total enrollments (Waits \& Lewis, 2003). Over $74 \%$ of community colleges offered online courses to students in 2000; this was over $76 \%$ in 2002 (Benson et al., 2008). Public institutions were more likely to offer distance education courses than were private institutions. In $2000-2001,90 \%$ of public two-year institutions offered distance education courses compared with $16 \%$ of private two-year institutions (Waits \& Lewis, 2003). In a study of 321 randomly selected public community colleges, researchers found that $45 \%$ of colleges offered online occupational program of some type (Githens \& Sauer, 2010). Some studies suggest that the average retention rate for students in distance education courses was $72 \%$ while traditional courses the rate was $78 \%$ (Lakken et al., 2008).

\section{Summary}

Over the past ten years, online enrollment has been growing in higher education, from 1.6 million in 2002 to over 5.6 million in 2009 (Allen \& Seaman, 2010). This growth in online distance education has generated new research and definitions of successful completion. Meyer (2006) suggests that online learning is becoming common practice as much as face-toface formats. Lakken et al. (2008) reported that the average retention rate for students in distance education courses was $72 \%$ while the rate in traditional courses was $78 \%$.

Online courses provide access to students who are not able to attend a traditional faceto-face course; this includes working adults and single parents (Githens et al., 2010). However, despite the quantity of students who express interest in taking an online class, the environment 
is not for everyone (Gibbs, 1998). Distance education requires more self-discipline, selfmotivation, self-regulation, and less reliance on other students (Lei \& Gupta, 2010).

In one American Federation of Teachers (AFT) study, 42\% of instructors reported higher dropout rates in their online courses than in their traditional courses; more research is needed to determine the accuracy of these numbers (AFT, 2000). Two-year, open enrollment, public institutions have the lowest retention rates due to the diversity of students being admitted (Beal \& Noel, 1979; Cowart, 1987). Attrition studies have shown that students at community colleges often stop or drop out due to the pressures of meeting the challenges of everyday life. The current definitions of the student at risk describe the majority of the students in American Community Colleges (Perez, 1998).

This study will provide another piece of the puzzle. It will focus on retention in online courses and demographic variables in relationship to withdrawing. 


\section{Chapter 3}

\section{Methodology}

This study looks at West Virginia Community and Technical College students who are withdrawing or not completing courses and the characteristics exhibited by this set of students across the Fall 2009 and Fall 2010 semesters.

\section{Research Design}

All community colleges in West Virginia submit board reports to WVCTCS (West Virginia Community and Technical College System) and HEPC (Higher Education Policy Commission) with certain required information about enrollment each semester. These agencies then use data to compare institutions across the state and to assist in providing funding to institutions and access to all West Virginia students. This study only focused on fall enrollment information since state funding is based on fall enrollment numbers.

WVCTCS and HEPC provided the documentation necessary for this study to the researcher (with student identification eliminated from the database) for the Fall 2009 and Fall 2010 semesters. The following independent variables will be used: grade in the course, gender of the student, ethnicity of the student, age of the student, West Virginia County of residence, high school attended, high school graduation year, number of semester credits, semester GPA, cumulative GPA, earned hours of the student, and number of transfer hours. These data was placed in SPSS and Chi Square statistics were computed to determine if there is any relationship among the variables. 


\section{Research Questions}

Why do these students withdraw across multiple variables? It is important for institutions to retain their students so that they can successfully progress through the coursework. If variables can be associated with the students who withdraw or do not complete, student services can review these variables in an attempt to help overcome the issues that are causing these students to not complete courses at a higher rate. This information can help college staff members to determine if appropriate courses need to be offered to retain students until completion.

RQ1: Is there a difference in completion rates between online, hybrid, and traditional courses? There may be a difference in completion rates between how the course is administrated; school administrators can make a determination on how they offer their courses.

RQ2: Is there a difference in grade achieved between online, hybrid, and traditional courses? There may be a difference in grade achieved between how the course is administrated; school administrators can make a determination on how they offer their courses.

RQ3: Is there a difference in completion rates between delivery methods used for online courses? If school administrators can see a difference between online delivery methods used, they can make a determination on which platform they would like to use for their courses.

RQ4: Is there a difference in grade achieved between delivery methods used for online courses? If school administrators can see a difference between online delivery methods used, they can make a determination on which platform they would like to use for their courses. 
RQ5: Is there an interaction between delivery method and degree of non-traditional delivery on completion rates? If school administrators can see a difference between delivery methods used, they can make a determination on which delivery method they would like to use for their courses.

RQ6: Is there an interaction between delivery method and degree of non-traditional delivery on grade achieved? If school administrators can see a difference between delivery methods used, they can make a determination on which delivery method they would like to use for their courses.

RQ7: Is there a significant difference in age and completion rate in an online course? One may assume that older, nontraditional students will withdraw at a higher rate than traditionally aged students, due to the integration of technology in courses. This study will show if there is a positive association between age and withdrawal rates, so the institution can determine if a specific population of students would need additional computer skills before they are successful in an online course.

RQ8: Is there a significant difference in age and grade achieved in an online course? One may assume that older, nontraditional students will earn lower grades than traditionally aged students, due to the integration of technology in courses. This study will show if there is a positive association between age and grade achieved, so the institution can determine if a specific population of students would need additional computer skills before they are successful in an online course.

RQ9: Is there a significant difference in age and completion rate in a hybrid course? One may assume that older, nontraditional students will withdraw at a higher rate than traditionally 
aged students, due to the integration of technology in courses. This study will show if there is a positive association between age and withdrawal rates, so the institution can determine if a specific population of students would need additional computer skills before they are successful in a hybrid course.

RQ10: Is there a significant difference in age and grade achieved in a hybrid course? One may assume that older, nontraditional students will earn lower grades than traditionally aged students, due to the integration of technology in courses. This study will show if there is a positive association between age and grade achieved, so the institution can determine if a specific population of students would need additional computer skills before they are successful in a hybrid course.

\section{Population and Sample}

A population is a group of people that a researcher wants to describe (Vogt \& Johnson, 2011). This study will examine all students enrolled in courses in community colleges in West Virginia during the fall 2009 and fall 2010 semesters. More specifically, data will be gathered from the following institutions: Blue Ridge Community and Technical College in Martinsburg, Bridgemont Community and Technical College in Montgomery, Eastern West Virginia Community and Technical College in Moorefield, Kanawha Valley Community and Technical College in Institute, Mountwest Community and Technical College in Huntington, New River Community and Technical College in Beckley, Pierpont Community and Technical College in Fairmont, Southern West Virginia Community and Technical College in Mount Gay, and West Virginia Northern Community College in Wheeling. 
The population is all of the community colleges and the sample is all students enrolled at all community colleges in West Virginia during the fall 2009 and fall 2010 semesters. The sample combines all institutions and these two specific semesters.

Instrument

WVCTCS and HEPC provided a dataset from Fall 2009 and Fall 2010, including documentation through an email to the researcher when requested. The data set combines all institutions and both semesters into one document. The format of the data was multiple, large Excel documents with the following column headings:

- Year

- Semester

- Institution

- Month of Birth

- Year of Birth

- Gender

- County of Residence

- Student Level

- Academically or Economically Disadvantaged

- Residency for Fee Purposes

- Type of Registration

- HS GPA on a 4.0 scale

- Student's Year of HS Graduation

- Previous Institution 
- GPA This Semester, End of Term

- Formal Withdraw at End of Term

- Cumulative Hours Earned, End of Term

- Cumulative GPA, End of Term

- Total Hours Earned at Another Accredited Institution

- College Hours Earned in High School

- $\quad$ CRN for Course (unique numbers assigned by course at each institution)

- Credit Attempted in Course

- Credit Earned in Course

- Grade Earned in Course

- Nontraditional Delivery in Course

- Institution Credits Earned (may be different from host institution for CTCs that are still administratively linked)

- Academic Level at which the course is being taught

- Degree of Nontraditional Delivery of the Course

- Primary method used to deliver nontraditional courses

- Secondary method used to deliver nontraditional courses

Once received, the information was imported into the SPSS (Software Package for Social Sciences) to perform statistical analysis. SPSS is a comprehensive system for analyzing data. SPSS can take data from almost any type of file and use them to generate reports, charts, plots of distributions and trends, descriptive statistics, and complex statistical analysis. 


\section{Statistical Analysis Procedures}

Once all data were entered into SPSS, a Chi-Square analysis was calculated (Analyze $\Rightarrow$ Descriptive Statistics $\Rightarrow$ Crosstabs) for the research questions (Field, 2005). A Chi-square test is a test of independence of two categorical variables. Essentially, it is a test whether two categorical variables have a relationship (Field, 2005). As a test statistic, it is a test of independence or a goodness of fit test (Vogt \& Johnson, 2011).

The simplest of the chi-square test is when a researcher wants to see if there are statistically significant differences between observed frequencies and the expected frequencies of the variables presented. The larger the difference is between the observed and expected frequencies, the larger the chi-square statistic. The larger the chi-square statistic, the less likely the observed difference is just due to chance, and the more statistically significant the finding is (Vogt \& Johnson, 2011).

\section{Institutional Review Board}

The researcher applied to the West Virginia University Institutional Review Board to receive human subject's clearance and ensure for the protection of human subjects. Following IRB approval, the researcher submitted an email with a brief explanation of the study, procedures used to collect data; benefits afforded participating institutions, and information regarding confidentiality to receive written permission to conduct the study from HEPC.

\section{Summary}

This design method was chosen for the study because the overarching question was to understand why students withdraw and do not complete courses. The data was compiled in SPSS and Chi-Square statistics performed. 


\section{Chapter 4}

\section{Results}

In this chapter, results are reported on data collected and analyzed to answer the Research Questions described in Chapter 3. As stated in Chapter 1, the research presented here examined withdrawal rates in online courses at public community colleges in West Virginia during the Fall 2009 and Fall 2010 semester snapshots. This study performs a comparative analysis based on existing data for which the WVCTCS institutions provide information for reporting. Data that can identify the student were removed, and the remaining data will be compared to determine the types of courses at each institution that have the highest withdrawal and failure rates. Several other points of data will also be compared for analysis. A total of 148,939 student records were reviewed of which 15,813 of these students withdrew from the course. In addition, 19,689 received a grade of $F$, and 15,637 received an unstandardized grade (see Table 4.1). As shown in Table 4.2, traditional courses made up $86.1 \%(128,242)$ of the total 148,939 courses. There were $11.9 \%(17,713)$ classified as online and $2.0 \%(2,984)$ as hybrid (see Table 4.2$)$.

Table 4.1

Frequency of Grades

\begin{tabular}{lcc}
\hline Grade & Frequency & Percent \\
\hline A-Superior & 38,774 & $26.0 \%$ \\
B-Good & 24,569 & $16.5 \%$ \\
C-Average & 15,245 & $10.2 \%$
\end{tabular}




$\begin{array}{llc}\text { D-Below Average } & 5,008 & 3.4 \% \\ \text { F-Failure } & 19,689 & 13.2 \% \\ \text { N-Incomplete } & 14,653 & 9.8 \% \\ \text { P-Passing } & 14,204 & 9.5 \% \\ \text { R-Progress } & 959 & 0.6 \% \\ \text { W-Withdraw } & 15,813 & 10.6 \% \\ \text { X-Audit } & 25 & 0.0 \% \\ \text { Total } & 148,939 & 100.0 \%\end{array}$

Table 4.2

Frequency of Courses

\begin{tabular}{llc}
\hline & Frequency & Percent \\
\hline $100 \%$ Online (1) & 17,713 & $11.9 \%$ \\
Hybrid (4) & 2,984 & $2.0 \%$ \\
Traditional (5) & 128,242 & $86.1 \%$ \\
Total & 148,939 & $100.0 \%$ \\
\hline
\end{tabular}

\section{Research Question 1}

Is there a difference in completion rates between online, hybrid, and traditional courses? There is a significant association between completion rates and delivery mode $\left(\chi^{2}(2)\right.$ $=566.94, p<.001$ ) (see Table 4.3). A closer examination of the cell percentages (“\% within Delivery") indicates that $9.9 \%$ of the students withdrew from traditional classes as compared to 
16.8\% from hybrid and $15.1 \%$ from online classes (see Table 4.4). Thus, students were more likely to withdraw from hybrid and online courses than they were from traditional courses.

Table 4.3

Withdraw versus Delivery Mode Chi-Square Tests

\begin{tabular}{llll}
\hline & Value & df & Asymp. Sig. (2-sided) \\
\hline Pearson Chi-Square & $566.937^{\mathrm{a}}$ & 2 & $p<.001$ \\
Likelihood Ratio & 515.046 & 2 & $p<.001$ \\
Linear-by-Linear Association & 470.821 & 1 & $p<.001$ \\
N of Valid Cases & 148,939 & & \\
\hline a. 0 cells (.0\%) have expected count less than 5. The minimum expected count is 316.81.
\end{tabular}

Table 4.4

Withdraw versus Delivery Mode Crosstabulation

Delivery Mode

Traditional

Online (1) Hybrid (4) (5) Total

\begin{tabular}{|c|c|c|c|c|c|c|}
\hline \multirow{4}{*}{$\begin{array}{l}3 \\
\frac{3}{0} \\
\frac{10}{0} \\
\frac{1}{ \pm} \\
3\end{array}$} & \multirow{4}{*}{ 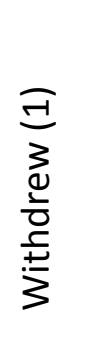 } & Count & 2,670 & 500 & 12,643 & 15,813 \\
\hline & & $\%$ within Withdraw & $16.9 \%$ & $3.2 \%$ & $80.0 \%$ & $100.0 \%$ \\
\hline & & $\%$ within Delivery & $15.1 \%$ & $16.8 \%$ & $9.9 \%$ & $10.6 \%$ \\
\hline & & $\%$ of Total & $1.8 \%$ & $0.3 \%$ & $8.5 \%$ & $10.6 \%$ \\
\hline & 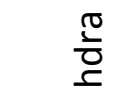 & Count & 15,043 & 2,484 & 115,599 & 133,126 \\
\hline
\end{tabular}




\begin{tabular}{|c|c|c|c|c|}
\hline$\%$ within Withdraw & $11.3 \%$ & $1.9 \%$ & $86.8 \%$ & $100.0 \%$ \\
\hline \% within Delivery & $84.9 \%$ & $83.2 \%$ & $90.1 \%$ & $89.4 \%$ \\
\hline$\%$ of Total & $10.1 \%$ & $1.7 \%$ & $77.6 \%$ & $89.4 \%$ \\
\hline Count & 17,713 & 2,984 & 128,242 & 148,939 \\
\hline \% within Withdraw & $11.9 \%$ & $2.0 \%$ & $86.1 \%$ & $100.0 \%$ \\
\hline \% within Delivery & $100.0 \%$ & $100.0 \%$ & $100.0 \%$ & $100.0 \%$ \\
\hline$\%$ of Total & $11.9 \%$ & $2.0 \%$ & $86.1 \%$ & $100.0 \%$ \\
\hline
\end{tabular}

\section{Research Question 2}

Is there a difference in grade achieved between online, hybrid, and traditional courses? There is a significant association between course grade and delivery mode $(\chi 2(12)=3747.88, p$ $<.001$ ) (see Table 4.5). A closer examination of the cell percentages ("\% within Delivery") indicates that $19.1 \%$ of the students from online courses received a grade of $F$ as compared to 14.3\% from hybrid and $12.4 \%$ from traditional classes (see Table 4.6). Thus, students enrolled in online courses received the greatest percentage of grades of $F$.

Table 4.5

Grade versus Delivery Mode Chi-Square Tests

\begin{tabular}{llll}
\hline & Value & df & Asymp. Sig. (2-sided) \\
\hline Pearson Chi-Square & $3747.884^{\mathrm{a}}$ & 12 & $p<.001$ \\
Likelihood Ratio & 4524.096 & 12 & $p<.001$ \\
Linear-by-Linear Association & 191.810 & 1 & $p<.001$ \\
N of Valid Cases & 148,939 & & \\
& & & \\
\hline
\end{tabular}


a. 0 cells (.0\%) have expected count less than 5 . The minimum expected count is 100.34 .

Table 4.6

Grade versus Delivery Mode Crosstabulation

Delivery Mode

Online (1) Hybrid (4) Traditional (5) Total

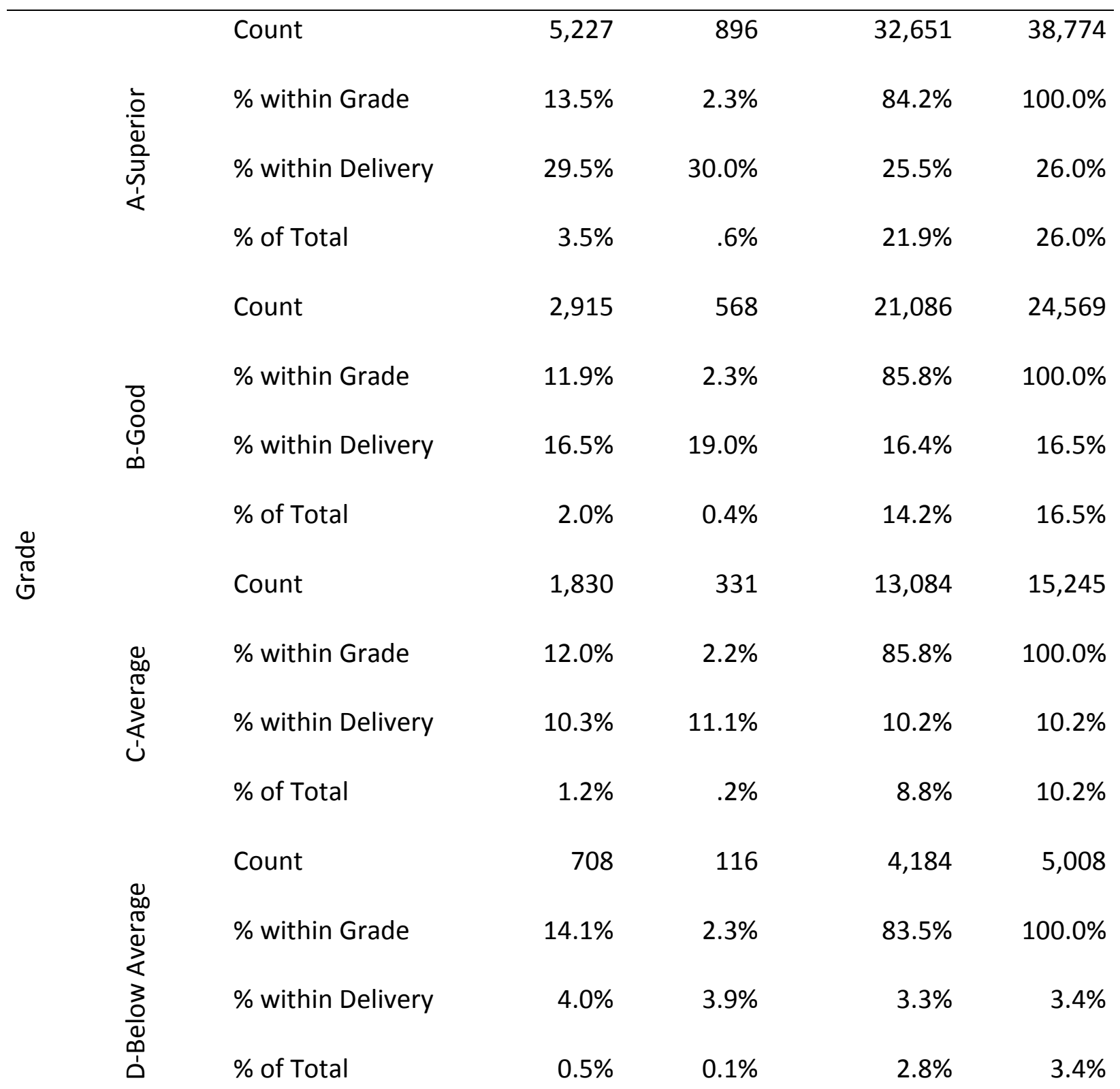




\begin{tabular}{|c|c|c|c|c|c|}
\hline & Count & 3381 & 426 & 15882 & 19689 \\
\hline \multirow{3}{*}{$\begin{array}{l}\frac{0}{J} \\
\frac{3}{\pi} \\
\frac{4}{1} \\
\frac{1}{4}\end{array}$} & $\%$ within Grade & $17.2 \%$ & $2.2 \%$ & $80.7 \%$ & $100.0 \%$ \\
\hline & \% within Delivery & $19.1 \%$ & $14.3 \%$ & $12.4 \%$ & $13.2 \%$ \\
\hline & $\%$ of Total & $2.3 \%$ & $.3 \%$ & $10.7 \%$ & $13.2 \%$ \\
\hline \multirow{5}{*}{ 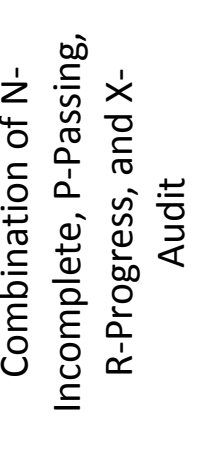 } & Count & 982 & 147 & 28,712 & 29,841 \\
\hline & $\%$ within Grade & $3.3 \%$ & $0.5 \%$ & $96.2 \%$ & $100.0 \%$ \\
\hline & $\%$ within Delivery & $5.5 \%$ & $4.9 \%$ & $22.4 \%$ & $20.0 \%$ \\
\hline & $\%$ of Total & $0.7 \%$ & $0.1 \%$ & $19.3 \%$ & $20.0 \%$ \\
\hline & Count & 2,670 & 500 & 12,643 & 15,813 \\
\hline \multirow{3}{*}{ 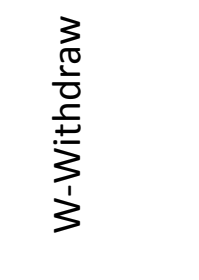 } & $\%$ within Grade & $16.9 \%$ & $3.2 \%$ & $80.0 \%$ & $100.0 \%$ \\
\hline & \% within Delivery & $15.1 \%$ & $16.8 \%$ & $9.9 \%$ & $10.6 \%$ \\
\hline & $\%$ of Total & $1.8 \%$ & $0.3 \%$ & $8.5 \%$ & $10.6 \%$ \\
\hline \multirow{4}{*}{0} & Count & 17,713 & 2,984 & 128,242 & 148,939 \\
\hline & $\%$ within Grade & $11.9 \%$ & $2.0 \%$ & $86.1 \%$ & $100.0 \%$ \\
\hline & $\%$ within Delivery & $100.0 \%$ & $100.0 \%$ & $100.0 \%$ & $100.0 \%$ \\
\hline & $\%$ of Total & $11.9 \%$ & $2.0 \%$ & $86.1 \%$ & $100.0 \%$ \\
\hline
\end{tabular}

\section{Research Question 3}

Is there a difference in completion rates between delivery methods used for online courses? There is no significant association between completion rates and delivery method $(\chi 2$ $(1)=.64, p=.43$ ) (see Table 4.7). Due to the amount of courses offered across the state, a comparison was only performed for online asynchronous and interactive video courses (see 
Table 4.8 and Table 4.9). Online, asynchronous courses were offered at all nine West Virginia Community and Technical Colleges, but only four of those institutions offered Interactive Video courses (see Table 4.10). Thus, there was not enough variety in the types of nontraditional courses offered throughout the State of West Virginia to adequately interpret the data.

Table 4.7

Withdraw versus Delivery Method Chi-Square Tests

\begin{tabular}{|c|c|c|c|c|c|}
\hline & & & Asymp. Sig. & Exact Sig. & Exact Sig. \\
\hline & Value & df & (2-sided) & (2-sided) & (1-sided) \\
\hline Pearson Chi-Square & $.638^{a}$ & 1 & $p>.425$ & & \\
\hline Continuity Correction ${ }^{b}$ & .595 & 1 & $p>.440$ & & \\
\hline Likelihood Ratio & .642 & 1 & $p>.423$ & & \\
\hline Fisher's Exact Test & & & & $p>.446$ & $p>.220$ \\
\hline Linear-by-Linear & .638 & 1 & $p>.425$ & & \\
\hline \multicolumn{6}{|l|}{ Association } \\
\hline $\mathrm{N}$ of Valid Cases & 20651 & & & & \\
\hline llc ( $0 \%)$ has & ed & & 5 Them & 20 & 68.68. \\
\hline
\end{tabular}

Table 4.8

Withdraw versus Delivery Method Crosstabulation 


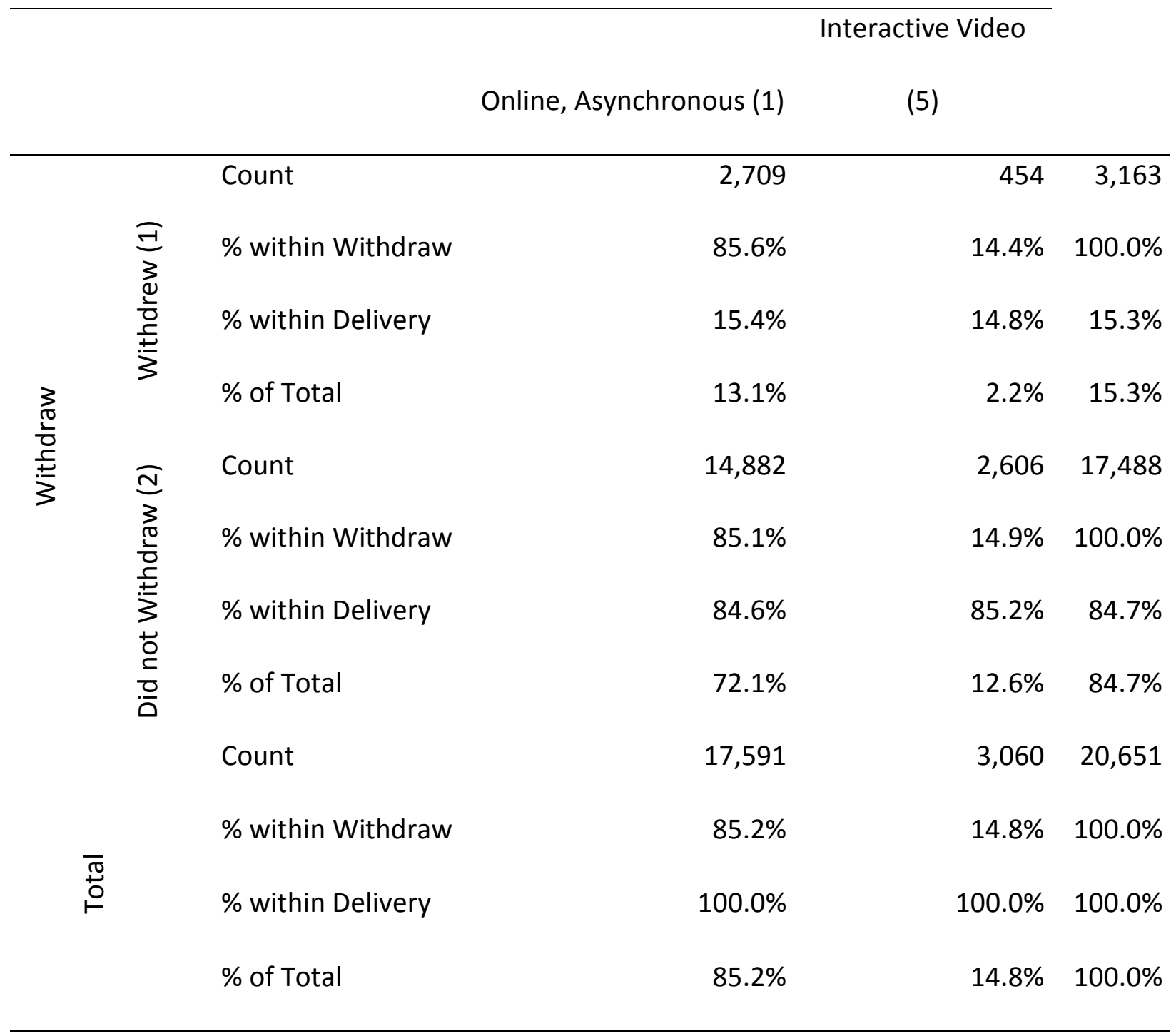

Table 4.9

Frequency of Delivery Method

\begin{tabular}{lcc}
\hline & Frequency & Percent \\
\hline Traditional (0) & 128,242 & 86.1 \\
Internet, Asynchronous (1) & 17,591 & 11.8 \\
Interactive Video (5) & 3,060 & 2.1
\end{tabular}


WV Public TV (6)

Correspondence (8)

Total
12

34

148,939
0.0

0.0

100.0

Table 4.10

Institution versus Delivery Method Crosstabulation

Delivery Method

Total

Traditional (0) Internet, Interactive WV Public Correspondence

Asynchronous Video (5) TV (6)

(1)

\begin{tabular}{|c|c|c|c|c|c|c|}
\hline 32 & 15,460 & 1,830 & 886 & 0 & 0 & 18176 \\
\hline 33 & 21,695 & 1,933 & 892 & 0 & 0 & 24520 \\
\hline 34 & 2,661 & 636 & 36 & 0 & 0 & 3333 \\
\hline 42 & 18,542 & 2,691 & 0 & 0 & 0 & 21233 \\
\hline$\frac{\overline{0}}{3}$ & 15,952 & 3,459 & 1,246 & 12 & 0 & 20669 \\
\hline 44 & 20,262 & 2,079 & 0 & 0 & 0 & 22341 \\
\hline 45 & 15,576 & 2,489 & 0 & 0 & 34 & 18099 \\
\hline 46 & 7,458 & 1,266 & 0 & 0 & 0 & 8724 \\
\hline 47 & 10,636 & 1,208 & 0 & 0 & 0 & 11844 \\
\hline Total & 128,242 & 17,591 & 3,060 & 12 & 34 & 148939 \\
\hline
\end{tabular}




\section{Research Question 4}

Is there a difference in grade achieved between delivery methods used for online courses? There is a significant association between course grade and delivery method $(\chi 2(6)=$ 205.62, $p$ <.001) (see Table 4.11). A closer examination of the cell percentages (see Table 4.12) indicates that students taking interactive video courses tend to get higher grades than those taking online courses. Students taking interactive video courses received more grades of A (31.1\% versus $29.3 \%)$, grades of B (21.4\% versus $16.0 \%)$, and grades of C ( $14.0 \%$ versus $9.8 \%)$. They also receive less grades of $\mathrm{D}(2.8 \%$ versus $4.2 \%)$, grades of $\mathrm{F}(11.4 \%$ versus $19.6 \%)$, and withdrawal (14.8\% versus $15.4 \%$ ) than students taking online asynchronous courses (see Table 4.12). Thus, West Virginia Community and Technical College Students tend to perform better in interactive video courses than in online asynchronous courses.

Table 4.11

Grade versus Delivery Method Chi-Square Tests

\begin{tabular}{llll}
\hline & Value & df & Asymp. Sig. (2-sided) \\
\hline Pearson Chi-Square & $205.622^{\mathrm{a}}$ & 6 & $p<.001$ \\
Likelihood Ratio & 213.177 & 6 & $p<.001$ \\
Linear-by-Linear & 40.882 & 1 & $p<.001$ \\
Association & & & \\
$\mathrm{N}$ of Valid Cases & 20651 & & \\
\hline a. 0 cells (.0\%) have expected count less than 5. The minimum expected count is 121.95.
\end{tabular}


Table 4.12

Grade versus Delivery Method Crosstabulation

\begin{tabular}{|c|c|c|c|c|c|}
\hline & & & Delivery M & thod & \\
\hline & & & Online, Asynchronous & Interactive Video & \\
\hline & & & (1) & (5) & Total \\
\hline & & Count & 5,153 & 952 & 6,105 \\
\hline & 흐 & $\%$ within Grade & $84.4 \%$ & $15.6 \%$ & $100.0 \%$ \\
\hline & $\stackrel{0}{气}$ & $\%$ within Delivery & $29.3 \%$ & $31.1 \%$ & $29.6 \%$ \\
\hline & & $\%$ of Total & $25.0 \%$ & $4.6 \%$ & $29.6 \%$ \\
\hline & & Count & 2,817 & 655 & 3,472 \\
\hline & & $\%$ within Grade & $81.1 \%$ & $18.9 \%$ & $100.0 \%$ \\
\hline & ọ & \% within Delivery & $16.0 \%$ & $21.4 \%$ & $16.8 \%$ \\
\hline & & $\%$ of Total & $13.6 \%$ & $3.2 \%$ & $16.8 \%$ \\
\hline & & Count & 1,731 & 428 & 2,159 \\
\hline & 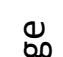 & $\%$ within Grade & $80.2 \%$ & $19.8 \%$ & $100.0 \%$ \\
\hline & $\stackrel{0}{i}$ & $\%$ within Delivery & $9.8 \%$ & $14.0 \%$ & $10.5 \%$ \\
\hline & & $\%$ of Total & $8.4 \%$ & $2.1 \%$ & $10.5 \%$ \\
\hline & & Count & 736 & 87 & 823 \\
\hline & $\begin{array}{l}\bar{\sigma} \\
\frac{\pi}{\pi} \\
\frac{\pi}{\alpha}\end{array}$ & $\%$ within Grade & $89.4 \%$ & $10.6 \%$ & $100.0 \%$ \\
\hline & $\underline{3}$ & $\%$ within Delivery & $4.2 \%$ & $2.8 \%$ & $4.0 \%$ \\
\hline & 它 & $\%$ of Total & $3.6 \%$ & $0.4 \%$ & $4.0 \%$ \\
\hline & $\frac{}{\frac{D}{\pi}}$ & $\cong$ Count & 3,451 & 350 & 3,801 \\
\hline
\end{tabular}




\begin{tabular}{|c|c|c|c|c|}
\hline & $\%$ within Grade & $90.8 \%$ & $9.2 \%$ & $100.0 \%$ \\
\hline & $\%$ within Delivery & $19.6 \%$ & $11.4 \%$ & $18.4 \%$ \\
\hline & $\%$ of Total & $16.7 \%$ & $1.7 \%$ & $18.4 \%$ \\
\hline , & Count & 994 & 134 & 1,128 \\
\hline 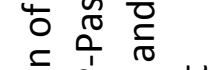 & $\%$ within Grade & $88.1 \%$ & $11.9 \%$ & $100.0 \%$ \\
\hline 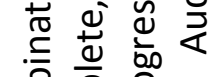 & $\%$ within Delivery & $5.7 \%$ & $4.4 \%$ & $5.5 \%$ \\
\hline ذ่ & $\%$ of Total & $4.8 \%$ & $0.6 \%$ & $5.5 \%$ \\
\hline & Count & 2,709 & 454 & 3,163 \\
\hline$\sum_{0}^{3}$ & $\%$ within Grade & $85.6 \%$ & $14.4 \%$ & $100.0 \%$ \\
\hline$\sum_{3}^{+1}$ & $\%$ within Delivery & $15.4 \%$ & $14.8 \%$ & $15.3 \%$ \\
\hline & $\%$ of Total & $13.1 \%$ & $2.2 \%$ & $15.3 \%$ \\
\hline & Count & 17,591 & 3,060 & 20,651 \\
\hline & $\%$ within Grade & $85.2 \%$ & $14.8 \%$ & $100.0 \%$ \\
\hline & $\%$ within Delivery & $100.0 \%$ & $100.0 \%$ & $100.0 \%$ \\
\hline & $\%$ of Total & $85.2 \%$ & $14.8 \%$ & $100.0 \%$ \\
\hline
\end{tabular}

\section{Research Question 5-6}

Is there an interaction between delivery method and degree of non-traditional delivery on completion rates? Is there an interaction between delivery method and degree of nontraditional delivery on grade achieved? There is a significant association between delivery method and degree of non-traditional delivery on completion rates and grade achieved, but only four institutions offer interactive video courses. Thus, there is not enough variety within the delivery methods offered throughout the schools to adequately interpret the data. 


\section{Research Question 7}

Is there a significant difference in age related to completion rate in an online course? There is a significant association between age and completion rates in online courses $(\chi 2(4)=$ 17.58, $p<.001$ ) (see Table 4.13). A closer examination of the cell percentages indicates, as students get older they tend to withdraw from a higher percentage of their online courses. The age groups were classified into ranges to be easier to read. Students who were under 24 withdrew at a rate of $14.6 \%$, students between the ages of 35-44 are most likely to withdraw at a rate of $20.7 \%$, students in the range of $45-54$ withdrew at a rate of $17.4 \%$, and students age 55 and over withdraw at a rate of $17.1 \%$ (see Table 4.14). Thus, the younger a student is the less likely they are to withdraw from an online course.

Table 4.13

Age Range versus Completion Rates in Online Courses Chi-Square Tests

\begin{tabular}{lccc}
\hline & Value & Df & Asymp. Sig. (2-sided) \\
\hline Pearson Chi-Square & $17.577^{\mathrm{a}}$ & 4 & $p<.001$ \\
Likelihood Ratio & 18.251 & 4 & $p<.001$ \\
Linear-by-Linear Association & 13.564 & 1 & $p<.001$ \\
N of Valid Cases & 17713 & & \\
& &
\end{tabular}

a. 0 cells $(.0 \%)$ have expected count less than 5 . The minimum expected count is 105.97 .

Table 4.14

Age Range versus Completion Rates in Online Courses Crosstabulation 


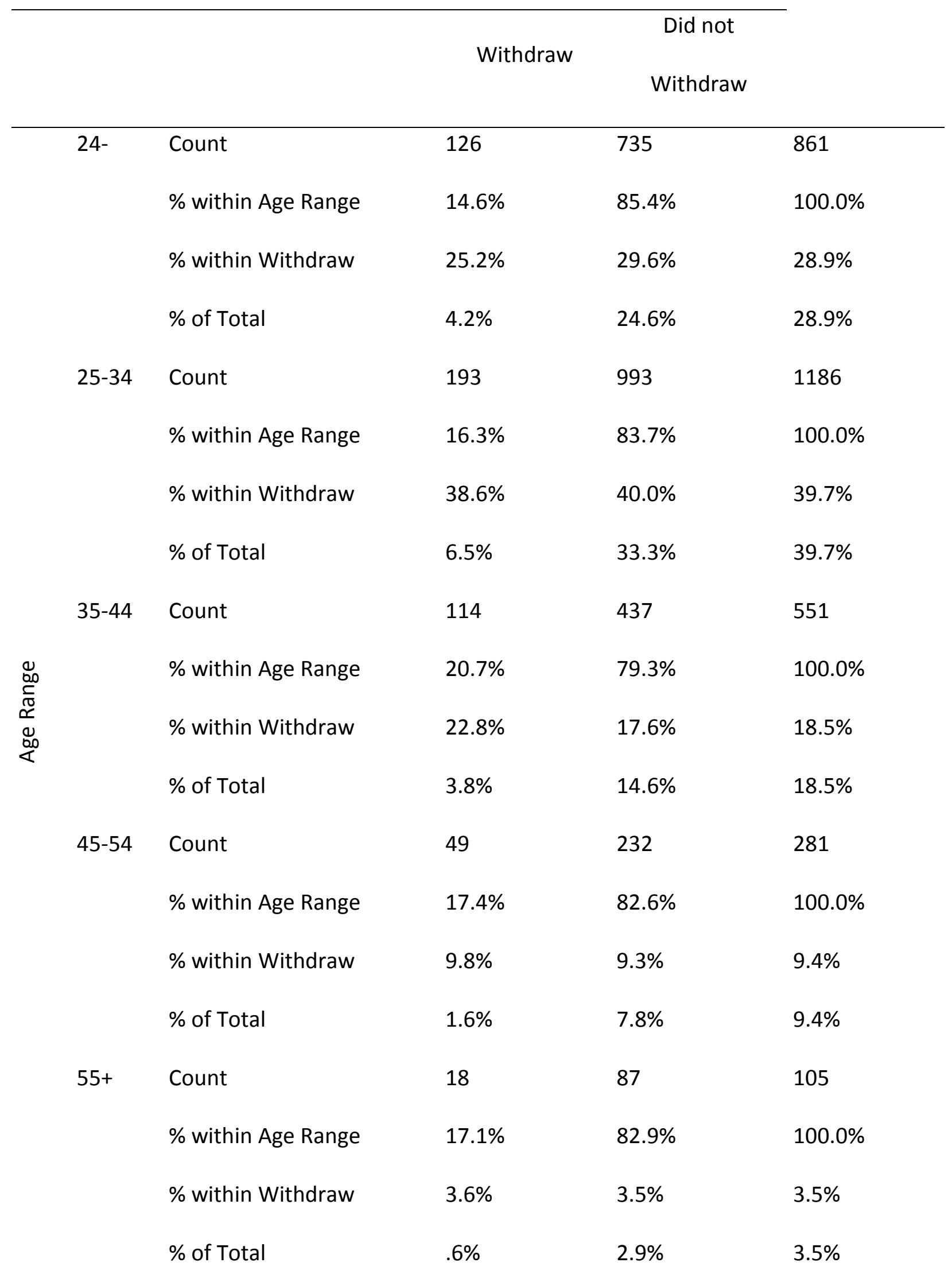




\begin{tabular}{|c|c|c|c|}
\hline Count & 500 & 2484 & 2984 \\
\hline$\%$ within Age Range & $16.8 \%$ & $83.2 \%$ & $100.0 \%$ \\
\hline \% within Withdraw & $100.0 \%$ & $100.0 \%$ & $100.0 \%$ \\
\hline$\%$ of Total & $16.8 \%$ & $83.2 \%$ & $100.0 \%$ \\
\hline
\end{tabular}

\section{Research Question 8}

Is there a significant difference in age and grade achieved in an online course? There is a highly significant association between age and grade achieved in online courses $(\chi 2(24)=$ $526.72, p<.001$ ) (see Table 4.15). When the same calculation is performed on the ages grouped together in a range, there is also significant difference $(\chi 2(4)=9.195, p=.056)$ (see Table 4.16). A closer examination of the cell percentages indicates, as students get older they tend to receive more grades of $A$ in their online courses. Students age 55 and older received grades of $A 47.2 \%$ of the time and students less than 24 received grades of $A 21.7 \%$ of the time in their online courses (see Table 4.17). Thus, the older a student is the more likely they are to receive a higher grade in an online course.

Table 4.15

Age versus Grade in Online Courses Chi-Square Tests

\begin{tabular}{llll}
\hline & Value & Df & Asymp. Sig. (2-sided) \\
\hline Pearson Chi-Square & $526.724^{\mathrm{a}}$ & 24 & $p<.001$ \\
Likelihood Ratio & 524.000 & 24 & $p<.001$ \\
Linear-by-Linear Association & 139.691 & 1 & $p<.001$ \\
N of Valid Cases & 17713 & & \\
& & & \\
\hline
\end{tabular}


a. 0 cells $(.0 \%)$ have expected count less than 5 . The minimum expected count is 28.10 .

Table 4.16

Age Range versus Grade in Online Courses Chi-Square Tests

\begin{tabular}{lccc}
\hline & Value & Df & Asymp. Sig. (2-sided) \\
\hline Pearson Chi-Square & $9.195^{\mathrm{a}}$ & 4 & $p=.056$ \\
Likelihood Ratio & 8.955 & 4 & $p=.062$ \\
Linear-by-Linear Association & 4.301 & 1 & $p=.038$ \\
N of Valid Cases & 2984 & & \\
& &
\end{tabular}

a. 0 cells $(.0 \%)$ have expected count less than 5 . The minimum expected count is 17.59 .

Table 4.17

Age Range versus Grade in Online Courses Crosstabulation

\begin{tabular}{|c|c|c|c|c|c|c|c|c|c|}
\hline & & & & & Grad & & & & \\
\hline & & & & & & & $N, P, R$, & & \\
\hline & & $A$ & B & $\mathrm{C}$ & $\mathrm{D}$ & $\mathrm{F}$ & $x$ & W & Total \\
\hline 24 & Count & 1012 & 805 & 604 & 230 & 1040 & 251 & 730 & 4672 \\
\hline- & $\%$ within Age & $21.7 \%$ & $17.2 \%$ & $12.9 \%$ & $4.9 \%$ & $22.3 \%$ & $5.4 \%$ & $15.6 \%$ & 100.0 \\
\hline 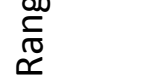 & Range & & & & & & & & $\%$ \\
\hline$\stackrel{\infty}{<}$ & $\%$ within Grade & $19.4 \%$ & $27.6 \%$ & $33.0 \%$ & $32.5 \%$ & $30.8 \%$ & $25.6 \%$ & $27.3 \%$ & $26.4 \%$ \\
\hline & $\%$ of Total & $5.7 \%$ & $4.5 \%$ & $3.4 \%$ & $1.3 \%$ & $5.9 \%$ & $1.4 \%$ & $4.1 \%$ & $26.4 \%$ \\
\hline
\end{tabular}


25 Count

- $\quad \%$ within Age

34 Range

$\%$ within Grade

$\%$ of Total

35 Count

- $\quad \%$ within Age

44 Range

$\%$ within Grade

$\%$ of Total

45 Count

- $\quad \%$ within Age

54 Range

$\%$ within Grade

$\%$ of Total

55 Count

$+\quad \%$ within Age

Range

$\%$ within Grade

$\%$ of Total

$\underline{\square}-$ Count $\begin{array}{llllll}1856 & 1146 & 705 & 287 & 1419 & 346\end{array}$

10816840

$27.1 \% \quad 16.8 \% \quad 10.3 \%$

$4.2 \%$

$20.7 \% \quad 5.1 \%$

$15.8 \% \quad 100.0$

$\%$

$\begin{array}{llllll}35.5 \% & 39.3 \% & 38.5 \% & 40.5 \% & 42.0 \% & 35.2 \%\end{array}$

$40.5 \% \quad 38.6 \%$

$10.5 \% \quad 6.5 \% \quad 4.0 \%$

$1.6 \%$

$8.0 \% \quad 2.0 \%$

$6.1 \% \quad 38.6 \%$ $\begin{array}{llllll}1204 & 548 & 305 & 114 & 573 & 213\end{array}$

$34.7 \% \quad 15.8 \%$

$8.8 \%$

$3.3 \% \quad 16.5 \% \quad 6.1 \%$

$14.8 \% \quad 100.0$

$\%$

$23.0 \% \quad 18.8 \% \quad 16.7 \%$

$16.1 \% \quad 16.9 \% \quad 21.7 \%$

$19.3 \% \quad 19.6 \%$

$6.8 \%$

$3.1 \%$

$1.7 \%$

$.6 \%$

$3.2 \%$

$1.2 \%$

$2.9 \% \quad 19.6 \%$

$823 \quad 327 \quad 165$

57

$279 \quad 114$

2612026

$40.6 \% \quad 16.1 \%$

$8.1 \%$

$2.8 \%$

$13.8 \% \quad 5.6 \%$

$12.9 \% \quad 100.0$

$\%$

$15.7 \% \quad 11.2 \% \quad 9.0 \%$

$8.1 \%$

$8.3 \%$

$11.6 \%$

$9.8 \% \quad 11.4 \%$

$\begin{array}{llllll}4.6 \% & 1.8 \% & .9 \% & .3 \% & 1.6 \% & .6 \%\end{array}$

$1.5 \% \quad 11.4 \%$ 33

89

$51 \quad 20$

70

58

$83 \quad 703$

$47.2 \%$

$12.7 \% \quad 7.3 \%$

$2.8 \%$

$10.0 \%$

$8.3 \%$

$11.8 \% \quad 100.0$

$\%$

$\begin{array}{llllll}6.4 \% & 3.1 \% & 2.8 \% & 2.8 \% & 2.1 \% & 5.9 \%\end{array}$

$3.1 \% \quad 4.0 \%$

$1.9 \% \quad .5 \% \quad .3 \%$

$.1 \% \quad .4 \% \quad .3 \%$

$.5 \% \quad 4.0 \%$

$\begin{array}{llllll}5227 & 2915 & 1830 & 708 & 3381 & 982\end{array}$

267017713 


\begin{tabular}{|c|c|c|c|c|c|c|c|c|}
\hline$\%$ within Age & $29.5 \%$ & $16.5 \%$ & $10.3 \%$ & $4.0 \%$ & $19.1 \%$ & $5.5 \%$ & $15.1 \%$ & 100.0 \\
\hline Range & & & & & & & & $\%$ \\
\hline \multirow[t]{2}{*}{$\%$ within Grade } & 100.0 & 100.0 & 100.0 & 100.0 & 100.0 & $100.0 \%$ & 100.0 & 100.0 \\
\hline & $\%$ & $\%$ & $\%$ & $\%$ & $\%$ & & $\%$ & $\%$ \\
\hline$\%$ of Total & $29.5 \%$ & $16.5 \%$ & $10.3 \%$ & $4.0 \%$ & $19.1 \%$ & $5.5 \%$ & $15.1 \%$ & 00 \\
\hline
\end{tabular}

\section{Research Question 9}

Is there a significant difference in age and completion rate in a hybrid course? There is a significant association between age and completion rates in hybrid courses $(\chi 2(49)=80.511, p$ $=.003$ ) (see Table 4.18). However, when the same calculation is performed on the ages grouped together in a range, there is no significant difference $(\chi 2(4)=9.195, p 0.56)$ (see Table 4.19). This nonsignificant relationship between age and hybrid course completion may be due to an artifact of the size of the data set.

Table 4.18

Age versus Completion in Hybrid Courses Chi-Square Tests

\begin{tabular}{llll}
\hline & Value & Df & Asymp. Sig. (2-sided) \\
\hline Pearson Chi-Square & $80.511^{\mathrm{a}}$ & 49 & $p=.003$ \\
Likelihood Ratio & 74.692 & 49 & $p=.010$ \\
Linear-by-Linear Association & 2.801 & 1 & $p=.094$ \\
N of Valid Cases & 2984 & & \\
\hline
\end{tabular}

a. 32 cells (32.0\%) have expected count less than 5 . The minimum expected count is 17 . 
Table 4.19

Age Range versus Completion in Hybrid Courses Chi-Square Tests

\begin{tabular}{llll}
\hline & Value & Df & Asymp. Sig. (2-sided) \\
\hline Pearson Chi-Square & $9.195^{\mathrm{a}}$ & 4 & $p=.056$ \\
Likelihood Ratio & 8.955 & 4 & $p=.062$ \\
Linear-by-Linear Association & 4.301 & 1 & $p=.038$ \\
N of Valid Cases & 2984 & & \\
& & & \\
\hline
\end{tabular}

a. 0 cells $(.0 \%)$ have expected count less than 5 . The minimum expected count is 17.59 .

\section{Research Question 10}

Is there a significant difference in age when related to grade achieved in a hybrid course? There is a significant association between age and grade achieved in hybrid courses ( $\chi 2$ $(294)=433.99, p<.001$ ) (see Table 4.20). There is also a significant association when the calculation is performed on the ages grouped together in a range, $(\chi 2(24)=77.09, p<.001)$ (see Table 4.21). A closer examination of the cell percentages indicates, as students get older they tend to receive more grades of $A$ in their hybrid courses. Students age 55 and older received a grade of $A 47.6 \%$ of the time and students less than 24 received a grade of $A 25.0 \%$ of the time in their hybrid courses (see Table 4.22). Thus, older students are more likely to receive better grades in hybrid courses. 
Table 4.20

Age versus Grade in Hybrid Courses Chi-Square Tests

\begin{tabular}{llll}
\hline & Value & Df & Asymp. Sig. (2-sided) \\
\hline Pearson Chi-Square & $433.990^{\mathrm{a}}$ & 294 & $p<.001$ \\
Likelihood Ratio & 437.327 & 294 & $p<.001$ \\
Linear-by-Linear Association & 1.098 & 1 & $p<.001$ \\
N of Valid Cases & 2984 & & \\
\hline
\end{tabular}

a. 196 cells (56.0\%) have expected count less than 5 . The minimum expected count is .04 .

Table 4.21

Age Range versus Grade in Hybrid Courses Chi-Square Tests

\begin{tabular}{llll}
\hline & Value & Df & Asymp. Sig. (2-sided) \\
\hline Pearson Chi-Square & $77.089^{\mathrm{a}}$ & 24 & $p<.001$ \\
Likelihood Ratio & 77.939 & 24 & $p<.001$ \\
Linear-by-Linear Association & 1.970 & 1 & $p=.160$ \\
McNemar-Bowker Test & $\cdot$ &. & $\cdot^{b}$ \\
N of Valid Cases & 2984 & &
\end{tabular}

a. 2 cells (5.7\%) have expected count less than 5 . The minimum expected count is 4.08 .

b. Computed only for a PxP table, where P must be greater than 1. 
Table 4.22

Age Range versus Grade in Hybrid Courses Crosstabulation

\begin{tabular}{|c|c|c|c|c|c|c|c|c|c|}
\hline & \multicolumn{7}{|c|}{ Grade } & \multirow[b]{3}{*}{ Total } \\
\hline & & \multirow[b]{2}{*}{ A } & \multirow[b]{2}{*}{$\mathrm{B}$} & \multirow[b]{2}{*}{ C } & \multirow[b]{2}{*}{ D } & \multicolumn{3}{|c|}{$N, P, R$} & \\
\hline & & & & & & $F$ & $x$ & W & \\
\hline \multirow{10}{*}{ 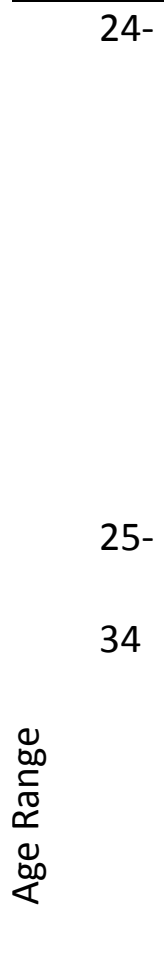 } & Count & 223 & 160 & 112 & 48 & 151 & 41 & 126 & 861 \\
\hline & $\%$ within Age & $25.9 \%$ & $18.6 \%$ & $13.0 \%$ & $5.6 \%$ & $17.5 \%$ & $4.8 \%$ & $14.6 \%$ & 100.0 \\
\hline & Range & & & & & & & & $\%$ \\
\hline & $\%$ within Grade & $24.9 \%$ & $28.2 \%$ & $33.8 \%$ & $41.4 \%$ & $35.4 \%$ & $27.9 \%$ & $25.2 \%$ & $28.9 \%$ \\
\hline & $\%$ of Total & $7.5 \%$ & $5.4 \%$ & $3.8 \%$ & $1.6 \%$ & $5.1 \%$ & $1.4 \%$ & $4.2 \%$ & $28.9 \%$ \\
\hline & Count & 349 & 239 & 131 & 43 & 179 & 52 & 193 & 1186 \\
\hline & $\%$ within Age & $29.4 \%$ & $20.2 \%$ & $11.0 \%$ & $3.6 \%$ & $15.1 \%$ & $4.4 \%$ & $16.3 \%$ & 100.0 \\
\hline & Range & & & & & & & & $\%$ \\
\hline & $\%$ within Grade & $39.0 \%$ & $42.1 \%$ & $39.6 \%$ & $37.1 \%$ & $42.0 \%$ & $35.4 \%$ & $38.6 \%$ & $39.7 \%$ \\
\hline & $\%$ of Total & $11.7 \%$ & $8.0 \%$ & $4.4 \%$ & $1.4 \%$ & $6.0 \%$ & $1.7 \%$ & $6.5 \%$ & $39.7 \%$ \\
\hline $35-$ & Count & 162 & 107 & 54 & 18 & 64 & 32 & 114 & 551 \\
\hline \multirow[t]{4}{*}{44} & $\%$ within Age & $29.4 \%$ & $19.4 \%$ & $9.8 \%$ & $3.3 \%$ & $11.6 \%$ & $5.8 \%$ & $20.7 \%$ & 100.0 \\
\hline & Range & & & & & & & & $\%$ \\
\hline & $\%$ within Grade & $18.1 \%$ & $18.8 \%$ & $16.3 \%$ & $15.5 \%$ & $15.0 \%$ & $21.8 \%$ & $22.8 \%$ & $18.5 \%$ \\
\hline & $\%$ of Total & $5.4 \%$ & $3.6 \%$ & $1.8 \%$ & $.6 \%$ & $2.1 \%$ & $1.1 \%$ & $3.8 \%$ & $18.5 \%$ \\
\hline $45-$ & Count & 112 & 45 & 26 & 4 & 27 & 18 & 49 & 281 \\
\hline
\end{tabular}




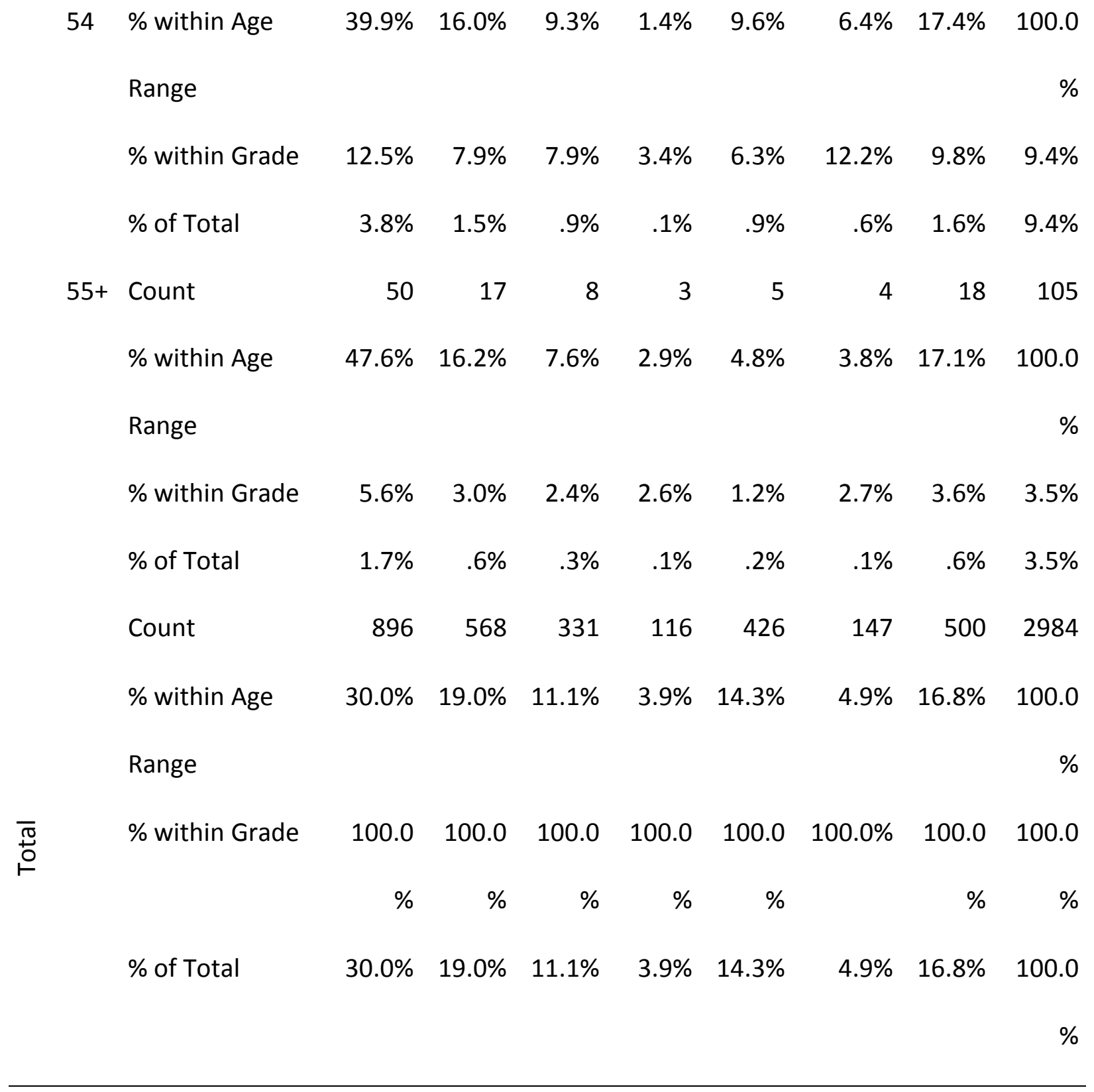

In chapter 4, results were reported on data collected and analyzed to answer the

Research Questions described in Chapter 3. Chapter 5 will summarize the data and discuss the results and recommendations for further research. 


\section{Chapter 5}

\section{Summary and Discussion}

This chapter summarizes the data presented in Chapter 4. It then provides a discussion of the results and recommendations for further research.

\section{Summary of the Results}

A total of 148,939 records were analyzed from all students enrolled in community and technical college courses across the State of West Virginia during the Fall 2009 and Fall 2010 semesters. Traditional courses were $86.1 \%$ of these courses, $2.0 \%$ were hybrid, and $11.9 \%$ were online. Over all courses, $26 \%$ of the total students received a grade of $A, 16.5 \%$ of the total students received a grade of $B, 10.2 \%$ of the total students received a grade of C, $3.4 \%$ of the total students received a grade of $D, 13.2 \%$ of students received a grade of $F$, and $10.6 \%$ of the total students withdrew from their course.

Students withdrew from hybrid classes at a rate of $16.8 \%$ and online at a rate of $15.1 \%$, while traditional classes had a 9.9\% withdraw rate. In addition to formally withdrawing, a larger number of online students (19.1\%) received a failing grade as compared to traditional courses (12.4\%), while hybrid students received failing grades $14.3 \%$ of the time. Yet in direct contrast, online students (29.5\%) generally received more grades of $A$ than traditional courses (25.5\%) with hybrid courses $(30.0 \%)$ receiving the highest amount.

West Virginia Community and Technical Colleges offered 128,242 (86.1\%) traditional courses during Fall 2009 and Fall 2010. They also offered 17,591 (11.8\%) online asynchronous courses, 3,060 (2.1\%) interactive video courses, 12 WV Public TV courses, and 34 correspondence courses. All institutions offered traditional and online courses, four institutions 
offered interactive video courses, and only one institution offered WV Public TV and Correspondence courses. Generally, students taking interactive video courses received more grades of A (31.1\% versus $29.3 \%$ for online asynchronous courses), grades of B ( $21.4 \%$ versus $16.0 \%)$, and grades of $C(14.0 \%$ versus $9.8 \%)$. They also receive less grades of $D(2.8 \%$ versus 4.2\%), grades of $F(11.4 \%$ versus $19.6 \%)$, and withdraw (14.8\% versus $15.4 \%)$ than students taking online asynchronous courses.

The older a student is the less likely they are to withdraw from an online or hybrid course and they also tend to receive higher grades in online and hybrid courses. Students over age 55 in online courses received more grades of $A(47.2 \%)$, grades of $B(12.7 \%)$, and they received less grades of $D(2.8 \%)$, grades of $F(10 \%)$, and withdraw $(11.8 \%)$. Students 24 or less received less grades of $A(21.7 \%)$, grades of $B(17.2 \%)$, and more grades of $D(4.9 \%)$, grades of $F$ (22.3\%), and withdraw (15.6\%). Students over age 55 in hybrid courses also received more grades of $A(47.6 \%)$, grades of $B(16.2 \%)$, and they received less grades of $D(2.9 \%)$, grades of $F$ (4.8\%), and withdraw (17.1\%). Students 24 or less received less grades of A (25.9\%), grades of B $(18.6 \%)$, and more grades of $D(5.6 \%)$, grades of $F(17.4 \%)$, and withdraw $(14.6 \%)$.

\section{Discussion of the Results}

As an administrator at a Community College in West Virginia, the results of the study are of great importance within my job duties. Part of that job is to make sure students are getting the most versatile and state of the art instruction that the school can provide. The number of online courses offered in West Virginia over the last 10 years has increased substantially with the technology. Are we doing an injustice by offering these courses to our students if they withdraw from the courses at a higher rate? From the results of this research, I would say no, 
but the results do change how I view retention rates in online and hybrid versus traditional courses.

Each semester I must review rosters at mid-term and final to look for trends developing within certain courses, disciplines, or instructors. After the results of this study, it is clear that more students withdraw from online courses across the state, and that is not unique to one of my instructors or courses.

Retention is a topic that is of the utmost importance to administrators at institutions of higher education. Community Colleges have the lowest retention rates due to the diversity of the students that are enrolling and the reason they are enrolling. There are many environmental factors such as family approval and support, which can affect their drop and withdraw rate. Although, this study does not dive into the specific issues associated with student drop and withdraw, it does address the need for such future research to combat these problems within institutions.

Students who withdraw have more Satisfactory Academic Progress issues with federal financial aid. If students are withdrawing or dropping in high numbers, they will no longer be eligible for federal financial aid at that institution. This means that the majority of those students will drop out of the college since they no longer have the monetary means to pay for their schooling. This greatly affects the institution's retention and graduation rates, which can also affect the institution's ability to receive additional income from the state. This can also be detrimental to the students since they are accumulating loan debts and have no college degree for money that they have borrowed from the federal government. 
Older students are possible more responsible and complete all assignment in courses and formally withdraw if they are struggling. Since the results of this student showed that older students (age 55 and older) tend to receive more grades of $A$, more grades of $B$, and more withdraws, we can assume that with age comes responsibility. These students are likely following correct college procedures and adhering to deadlines about formally withdrawing and submitting assignments to their instructors.

This study has shown that student persistence is greater in courses offered at a distance, which can partially be due to the lack of physical contact with the students and the instructor, self-discipline, or good study habits. Once a student gets behind in an online or hybrid course, it is much harder for them to catch up due to the independent nature of the courses. Students then have no recourse except to cease attending or formally withdraw from the course they are struggling.

With the results of this study, community colleges can look deeper into the need to retain students who are taking online courses and the struggles they deal with. Since community colleges are open access institutions and cannot increase these numbers by developing more stringent entrance guideline, they need to properly prepare the students they admit to be successful in online courses. This can include orientations or special classes to assist students in being successful with the independent nature of online coursework.

\section{Limitations of the Study}

One of the assumptions of a chi-squared test is that each person can only contribute once to the data. Chi-square tests also have frequencies above 5 . In this research, students may be taking more than one online course and therefore are counted more than once in the 
data set. Since we have removed identifiable student characteristics, this is unavoidable in this design.

The results of this study are limited to online students at West Virginia public community colleges. It may not apply to students at a four-year institution or students in other states.

\section{Further Research}

This study only looks at how many students are withdrawing and not passing online courses at West Virginia Community and Technical Colleges, it does not look into why these students withdraw at a higher rate than traditional courses. Further research is needed on the reasons why they withdraw and what can be done to prevent their departure.

This research has prompted me to track additional reasons why students are withdrawing at my own institution. Each time a student withdraws from any class, there is a brief questionnaire on our withdraw from to indicate the reasons why. We also ask them if they would like to speak to someone personally about the reasons they are withdrawing so we can attempt to combat the reasons we can control.

One important topic for further research is to consider how many credits a student is taking in a given semester and how this affects their drop out and withdraw status. The information provided to the researcher did not allow for this analysis, but this topic is of great importance. If a student is taking 15-19 credit hours in one semester, how does that affect their drop out or withdraw rate as compared to someone taking 9-12 credit hours in a semester. Does their overall GPA have any impact on their drop out and withdraw rate? 
Students withdraw and drop out of all classes for reasons that the institution may or may not know. These include academic discipline, academic self-confidence, communication skills, commitment to college, emotional control, general determination, goal striving, social activity, social connection, and study skills (Robbins et al., 2006). Academic deficiency is the number one reason students depart from higher education (Zhai \& Newcomb, 2000). When institutions realize the different rates that students are withdrawing or dropping out of online, hybrid, and live courses they can begin to search for the issues why students are not succeeding in these individual courses, which can lead to reduced drop out and withdraw rates, which should increase the institution's retention and graduation rates. 


\section{Appendix}

\section{WVU IRB Approval}

The following IRB Protocol has been marked as Exempt.

Tracking \#: H-24409

PI: Chapman, Paul

Title: West Virginia Community and Technical College Students Withdrawing From Online Courses: A Study by Institution Across Fall 2009 and Fall 2010 Semester Snapshots

The BRAAN2 website can be accessed by clicking the following link: BRAAN2 Login

\section{Legend for Data Set}

Variables:

A. YR - Year

- 2009

- 2010

B. SEM-Semester

- Fall, End of Term

C. INST - Institution

- 32 = Southern West Virginia Comm \& Tech College

- $33=$ West Virginia Northern Community College

- 34 = Eastern WV Community and Technical College 
- $42=$ Mountwest Community and Technical College

- $43=$ New River Community and Technical College

- 44 = Pierpont Community and Technical College

- 45 = Blue Ridge Community and Technical College

- $46=$ Bridgemont Community and Technical College

- $47=$ Kanawha Valley Community and Technical College

D. MO_BIRTH - Month of Birth

E. YR_BIRTH - Year of Birth

F. SEX-Gender

- $\mathrm{M}=$ Male

- $\mathrm{F}=$ Female

G. COUNTY - County of Residence

\begin{tabular}{|c|c|c|c|}
\hline 01 Barbour & 15 Hancock & 29 Mineral & 43 Ritchie \\
\hline 02 Berkeley & 16 Hardy & 30 Mingo & 44 Roane \\
\hline 03 Boone & 17 Harrison & 31 Monongalia & 45 Summers \\
\hline 04 Braxton & 18 Jackson & 32 Monroe & 46 Taylor \\
\hline 05 Brooke & 19 Jefferson & 33 Morgan & 47 Tucker \\
\hline 06 Cabell & 20 Kanawha & 34 Nicholas & 48 Tyler \\
\hline 07 Calhoun & 21 Lewis & 35 Ohio & 49 Upshur \\
\hline 08 Clay & 22 Lincoln & 36 Pendleton & 50 Wayne \\
\hline 09 Doddridge & 23 Logan & 37 Pleasants & 51 Webster \\
\hline 10 Fayette & 24 Marion & 38 Pocahontas & s52 Wetzel \\
\hline
\end{tabular}


11 Gilmer 25 Marshall 39 Preston 53 Wirt

12 Grant 26 Mason 40 Putnam 54 Wood

13 Greenbrier 27 McDowell 41 Raleigh 55 Wyoming

14 Hampshire 28 Mercer 42 Randolph 00 Out of State

H. STDT_LVL - Student Level

- $\mathrm{A}=$ Unclassified (Undergraduate)

- $\quad B=$ Lower-Level Student (Freshman)

- $\quad \mathrm{C}=$ Lower-Level Student (Sophomore)

- $\quad \mathrm{D}=$ Upper-Level Student (Junior)

- $\mathrm{E}=$ Upper-Level Student (Senior or Fifth-Year Student)

I. DISADVANTAGED - Academically or Economically Disadvantaged

- $1=$ Not Applicable or not known

- 2 = Academically Disadvantaged

- 3 = Economically Disadvantaged

- $\quad 4$ = Both Academically Disadvantaged and Economically Disadvantaged

J. RES_FEES - Residency for Fee Purposes

- $1=$ In-State

- 2 = Out-of-State

- 3 = SREB Academic Common Market

- 4 = Reciprocity agreement

- $5=$ Metro agreement

- $6=$ Disaster relief 
K. TYPE_REGE - Type of Registration

- 1 = First-Time Freshman

- 2 = Returning Student

- $3=$ Readmitted Student

- $6=$ Transfer Student

- $8=$ High School Student Taking College Courses

- $9=$ Other

L. HS_GPA - HS GPA on a 4.0 scale

M. YR_GRAD_HS - Student's Year of HS Graduation

N. PREV_INST - Previous Institution

- $\quad 01=$ Marshall University

- $\quad 02=$ West Virginia University

- $09=$ West Virginia School of Osteopathic Medicine

- $11=$ College of Graduate Studies

- $\quad 21=$ Bluefield State College

- $22=$ Concord University

- $\quad 23$ = Fairmont State University

- 24 = Glenville State College

- 25 = Shepherd University

- $\quad 26=$ West Liberty University

- $\quad 27=$ West Virginia University Institute of Technology

- $\quad 28=$ West Virginia State University 
- $31=$ WVU at Parkersburg

- $\quad 32$ = Southern West Virginia Comm \& Tech College

- $33=$ West Virginia Northern Community College

- 34 = Eastern WV Community and Technical College

- 41 = Potomac State College of WVU

- $42=$ Mountwest Community and Technical College

- $\quad 43$ = New River Community and Technical College

- $44=$ Pierpont Community and Technical College

- 45 = Blue Ridge Community and Technical College

- $46=$ Bridgemont Community and Technical College

- 47 = Kanawha Valley Community and Technical College

- $50=$ Appalachian Bible College

- 51 = Alderson-Broaddus College

- $52=$ Bethany College

- 53 = Davis \& Elkins College

- 54 = University of Charleston

- $56=$ WV Wesleyan College

- $\quad 57=$ Wheeling Jesuit University

- $61=$ Mountain State University

- 63 = Ohio Valley University

- $90=$ Other Institution

- $\quad 00=$ Not Applicable 
O. SEM_GPA - GPA This Semester, End of Term

P. WITHDRAW - Formal Withdraw at End of Term

- $\quad W=$ Student has formally withdrawn from current institution

- 0 (zero) $=$ Not applicable

Q. CUM_HRS_EARN - Cumulative Hours Earned, End of Term

R. CUM_GPA - Cumulative GPA, End of Term

S. HRS_EARN_PREV_INST - Total Hours Earned at Another Accredited Institution

T. HS_CR - College Hours Earned in High School

U. CINDEX - CRN for Course (unique numbers assigned by course at each institution)

V. CR_ATT - Credit Attempted in Course

W. CR_EARN - Credit Earned in Course

X. GRADE - Grade Earned in Course

- $A, B, C, D, F$

- $\quad X=$ Indicates audit.

- $\mathrm{P}=$ Indicates Passing Pass-Fail or Credit/No-Credit course.

- $\mathrm{R}=$ Indicates $\mathrm{pRogress}$ in a course that continues past the semester.

- $\quad \mathrm{N}=$ Indicates grade Not yet received, or incomplete.

- $W=$ Student Withdrew from course.

Y. NONTRAD -Nontraditional Delivery in Course

- $Y=Y e s$

- $\mathrm{N}=\mathrm{No}$ 
Z. CRS_INST - Institution credits earned (may be different from host institution for CTC'S that are still administratively linked)

AA. LV -Academic Level at which the course is being taught

- $\quad \mathrm{B}=$ Lower-Level Bachelor's

- $\mathrm{C}=$ Career-Technical

- $\quad F=$ Foundation Level

BB. DEG_NONTRAD -Degree of Nontraditional Delivery of the Course

- $1=100 \%$ non-traditional delivery

- $4=50 \%$ to $99 \%$ non-traditional delivery

- $5=<50 \%$ non-traditional delivery

CC. NONTRAD_1 - Indicates the primary method used to deliver nontraditional courses.

- $0=$ Less than $50 \%$ non-traditional delivery

- 1 = Internet, Asynchronous (includes cached video)

- $\quad 2$ = Internet, Synchronous (includes cached video)

- 3 = Satellite, SATNET

- 4 = Satellite, Other

- 5 = Interactive video

- 6 = WV Public TV (HEITV)

- $\quad 7$ = Physical electronic media (videotape, audiotape, $C D$, or other)

- $8=$ Correspondence

- $9=$ Other method

DD.NONTRAD_2 - Indicates the secondary method used to deliver nontraditional courses. 
- $0=$ Less than $50 \%$ non-traditional delivery

- $\quad 1$ = Internet, Asynchronous (includes cached video)

- $\quad 2$ = Internet, Synchronous (includes cached video)

- 3 = Satellite, SATNET

- 4 = Satellite, Other

- $\quad 5=$ Interactive video

- 6 = WV Public TV (HEITV)

- 7 = Physical electronic media (videotape, audiotape, $C D$, or other)

- $8=$ Correspondence

- $9=$ Other method 


\section{References}

About IPEDS. (n.d.). Retrieved July 18, 2009, from National Center for Education Statistics: http://nces.ed.gov/ipeds/about

Allen, I. \& Seaman, J. (2003). Sizing the opportunity: The quality and extent of online education in the United States, 2002 and 2003. The Sloan Consortium and Babson Survey Research Group: Needham, MA. Retrieved on October 1, 2010 from http://sloanconsortium.org/sites/default/files/sizing_opportunity_2.pdf

Allen, I. \& Seaman, J. (2007). Online nation: Five years of growth in online learning. The Sloan Consortium and Babson Survey Research Group: Needham, MA. Retrieved on October 20, 2010 from http://sloanconsortium.org/publications/survey/pdf/online_nation.pdf Allen, I. \& Seaman, J. (2010). Learning on demand: Online education in the United States, 2010. The Sloan Consortium and Babson Survey Research Group: Needham, MA. Retrieved on November 2, 2010 from http://sloanconsortium.org/sites/default/files/pages/learningondemand-7.pdf American Association of Community Colleges [AACC]. (2010a). 2010 Fact Sheet. Retrieved from http://www.aacc.nche.edu/AboutCC/Documents/factsheet2010.pdf on October 24, 2010.

American Association of Community Colleges [AACC]. (2010b). Community Colleges Past to Present. Retrieved from http://www.aacc.nche.edu/AboutCC/history/Pages/pasttopresent.aspx on October 24, 2010. 
American Association of Community Colleges [AACC]. (2010c). Students at community colleges. Retrieved from http://www.aacc.nche.edu/AboutCC/Trends/Pages/studentsatcommunitycolleges.aspx on October 24, 2010.

American Federation of Teachers (AFT). (2000 May). Distance education: Guidelines for good practice. (Number 36-0693). Retrieved September 25, 2010 from http://www.aft.org/higher_ed/downloadable/distance.pdf

Bailey, T., Jenkins, D., \& Leinbach, T. (2005 September). Graduation rates, student goals, and measuring community college effectiveness [Electronic Version]. Community College Research Center Brief, 28, 1-4. (1526-2019).

Beal, P. \& Noel, L. (1979). What works in student retention? A preliminary summary of a national survey conducted jointly by the American College Testing Program and the National Center for Higher Education Management Systems. ACT, Inc. Retrieved September 1, 2010 from ERIC database. (ED180348).

Benson, A., Johnson, S., Duncan, J., Shinkareva, O., Taylor, G., \& Tod Treat, G. (2008). Community college participation in distance learning for career and technical education [Electronic Version]. Community College Journal of Research and Practice, 32, 665-687. (1521-0413).

Braxton, J., Hirschy, A., \& McClendon, S. (2004). Understanding and reducing college student departure. ASHE-ERIC Higher Education Report, 30 (3), 1-87. 
Cabnera, A., Nora, A., \& Castaneda, M. (1993 March-April). College persistence: Structural equations modeling test of an integrated model of student retention [Electronic Version]. Journal of Higher Education, 64 (2), 123-139.

Chen, R. \& DesJardins, S. (2010 March/April). Investigating the impact of financial aid on student dropout rates: Racial and ethnic differences. The Journal of Higher Education, $81(2), 179-208$.

Clemetsen, B. \& Balazer, J. (2008). Paving the path to success: Community college and university degree partnerships. College and University, 83 (3), 12-19.

Cohen, A. (1998). The shaping of American higher education: Emergence and growth of the contemporary system. San Francisco: Jossey-Bass Publishers.

Cowart, S. (1987). What works in student retention in state colleges and universities? ACT, Inc. Retrieved September 1, 2010 from ERIC database. (ED347928).

Cox, R. (2005 August). Online education as an institutional myth: Rituals and realities at community colleges [Electronic Version]. Teachers College Record, 107 (8), 1754-1787. (0161-4681).

Encarta Dictionary. (2009). Retrieved October 8, 2010 from http://encarta.msn.com/encnet/features/dictionary/dictionaryhome.aspx

Epstein, J. (2010, October 21). Measuring two-year students' success. Inside Higher Ed. Retrieved October 21, 2010 from http://www.insidehighered/com/layout/set/print/news/2010/10/21/data

Federal Student Aid. (n.d.). Retrieved October 21, 2011, from Federal Student Aid: http://www.ifap.ed.gov/regcomps/doc2612_bodyoftext.htm 
Field, A. (2005). Discovering statistics using SPSS (Second Edition). London, Sage Publications.

Floyd, D. (2003). Distance learning in community colleges: Leadership challenges for change and development [Electronic Version]. Community College Journal of Research and Practice, 27, 337-347. (DOI: 10.1080/10668920390128960).

Gao, H., Hughes, W., O'Rear, M., \& Fendley, W. (2002, June 3). Developing structural equation models to determine factors contributing to student graduation and retention: Are there differences for native students and transfers? Paper presented at the $43^{\text {rd }}$ Annual Research Forum of the Association for International Research (Toronto, Ontario, Canada). Retrieved on September 6, 2010 from ERIC database. (ED478834).

Gibbs, W. (1998 Fall). Implementing online learning environments [Electronic Version]. Journal of Computing in Higher Education, 10 (1), 16-37.

Githens, R. \& Sauer, T. (2010 June/July). Going green online: Distance learning prepares students for success in green collar job markets. Community College Journal, 80 (6), 3235).

Githens, R., Crawford, F., \& Sauer, T. (2010 February 24). Online occupational education in community colleges: Prevalence and contextual factors. National Research Center for Career and Technical Education. Retrieved August 31, 2010 from ERIC database. (ED510268).

Habley, W. \& McClanahan, R. (2004). What works in student retention? All survey colleges. ACT, Inc. Retrieved September 1, 2010 from ERIC database. (ED500455). 
Habley, W., Valiga, M., McClanahan, R., \& Burkum, K. (2010). What works in student retention? Fourth national survey. Community colleges report. ACT, Inc. Retrieved September 1, 2010 from ERIC database. (ED510455).

Hardy, K. \& Bower, B. (2004 Winter). Instructional and work life issues for distance learning faculty [Electronic Version]. New Directions for Community Colleges, 128, 47-54.

Hirumi, A. (2005). In search of quality: An analysis of e-learning guidelines and specifications [Electronic Version]. The Quarterly Review of Distance Education, 6 (4), 309-330).

Hossler, D. (2006). Managing student retention: Is the glass half-full, half-empty, or simply empty? College and University, 81 (2), 11-14.

Hrastinski, S. (2008 November 4). A study of asynchronous and synchronous e-learning methods discovered that each supports different purposes [Electronic Version]. EDUCAUSE Quarterly, 31 (4), 51-55.

Hutt, C. Bray, N., Jones, J., Leach, K., \& Ward, J. (2010). Enrolling the ride: A case study of purposeful campus enrollment increases. College and University, 85 (4), 10-17. IPEDS Glossary. (n.d.). Retrieved December 1, 2010, from National Center for Education Statistics: http://nces.ed.gov/ipeds/glossary/

Jackson, S. (2005). Lost in translation: Turning on-ground courses into effective web-based learning [Electronic Version]. Distance Education Report, June 15, 2005.

Kolowich, S. (2010, October 22). Changing course. Inside Higher Ed. Retrieved October 11, 2010 from http://www.insidehighered.com/layout/set/print/news/2010/10/22/remedial 
Lakken, F., Womer, L., \& Mullins, C. (2008). 2007 distance education survey results: Tracking the impact of e-learning at community colleges [Electronic Version]. Catalyst, 37 (1), 38. (ISSN: 21519390).

Lederman, D. (2010, October 11). Calculating the cost of dropouts. Inside Higher Ed. Retrieved October 11, 2010 from http://www.insidehighered.com/layout/set/print/news/2 010/10/11/dropout

Lei, S. \& Gupta, R. (2010). College distance education courses: Evaluating benefits and costs from institutions, faculty, and student perspectives [Electronic Version]. Education, 130 (4), 616-631.

Luo, M., Williams, J., \& Vieweg, B. (2007). Transitioning transfer students: Interactive factors that influence first year retention. College and University, 83 (2), 8-19.

Meyer, K. (2002). Quality in distance education: Focus on on-line learning [Electronic Version]. ASHE-ERIC Higher Education Report, 29 (4), 1-121. (DOI: 10.1002/aehe.2904).

Meyer, K. (2006). Quality in distance education: Focus on on-line learning [Electronic Version]. ASHE-ERIC Higher Education Report, 32 (1), 1-123. (DOI: 10.1002/aehe.3201).

Miller, T. \& Herreid, C. (2008). Analysis of variables to predict first year persistence using logic regression analysis at the University of South Florida. College and University, 83 (3), 211.

Miller, T. \& Tyree, T. (2009). Using a model that predicts individual student attrition to intervene with those who are most at risk. College and University, 84 (3), 12-19.

Miller, T. (2007). Will they stay or go? Predicting the risk of attrition at a larger public university. College and University, 83 (2), 2-7. 
Miller, T., Tyree, T. Riegier, K., \& Herreid, C. (2010). Results of the use of a model that predicts individual student attrition with those who are most at risk. College and University, 85 (3), 12-19.

National Center for Education Statistics (NCES), U.S. Department of Education, Higher Education General Information Survey (HEGIS). (2005). Fall Enrollment in Colleges and Universities surveys, 1970 and 1980; 1990 through 2004 Integrated Education Data System. Fall Enrollment Survey and Spring 2001 through Spring 2005; and Projections of Education Statistics to 2014. Retrieved May 2, 2008, from http://nces.ed.gov/programs/digest/d05/tables/dt05_172.asp

Ogunleye, A. (2010 January). Evaluating an online learning programme from students' perspective [Electronic Version]. Journal of College Teaching and Learning, 7 (1), 79-89. (ISSN 1544-0389).

Orellana, A. (2006). Class size and interaction in online courses [Electronic Version]. The Quarterly Review of Distance Education, 7 (3), 229-248. (ISSN: 1528-3518).

Parsad, B., \& Lewis, L. (2008). Distance Education at Degree-Granting Postsecondary Institutions: 2006-07 (NCES 2009-044). National Center for Education Statistics, Institute of Education Sciences, U.S. Department of Education: Washington, DC. Retrieved November 4, 2010 from http://nces.ed.gov/pubs2009/2009044.pdf

Perez, L. (1998 Summer). Sorting, supporting, connecting, and transforming: Intervention strategies for students at risk [Electronic Version]. Community College Review, 26 (1), 63-78. (ISSN: 0091-5521). 
Robbins, S., Allen, J., Casillas, A., Peterson, C., \& Le, H. (2006). Unraveling the differential effects of motivational and skills, social, and self-management measures from traditional predictors of college outcomes [Electronic Version]. Journal of Educational Psychology, 98 (3), 598-616. (DOI:10.1037/0022-0663.98.3.598).

Ronco, S., \& Cahill, J. (2004 May). Does it matter who's in the classroom? Effect of instructor type on student retention, achievement, and satisfaction. Paper presented at the $44^{\text {th }}$ Annual Forum of the Association for International Research (Boston, Massachusetts). Retrieved September 1, 2010 from ERIC database. (ED491000).

Schaeffer, S. (2010 September/October). Online learning is here to stay. EdTech: Focus on Higher Education, 6 (3), 9.

Schneider, M. (2010 October). Finishing the first lap: The cost of first-year student attrition in America's four-year colleges and universities. American Institute for Research (AIR). Retrieved October 11, 2010 from http://www.air.org/files/AIR_Schneider_Finishing_the_First_Lap_Oct10.pdf

Snyder, T., Dillow, S., \& Hoffman, C. (2008). Digest of Education Statistics. Retrieved December 13, 2010, from National Center for Education Statistics: http://nces.ed.gov/pubsearch/pubsinfo.asp?pubid=2009020

Stone, M. (2007). E-learning application for career and technical education [Electronic Version]. Techniques, May 2007. www.acteonline.org

Tracey, M. \& Richey, R. (2005). The evolution of distance education [Electronic Version]. Distance Learning, 2 (6), 17-21. 
Vogt, W. \& Johnson, R. (2011). Dictionary of statistics \& methodology: A nontechnical guide for the social sciences. Los Angeles, Sage Publications.

Waits, T. \& Lewis, L. (2003). Distance Education at Degree-Granting Postsecondary Institutions: 2000-2001 (NCES 2003-017). U.S. Department of Education, National Center for Education Statistics: Washington, DC. Retrieved November 1, 2010 from http://nces.ed.gov/pubs2003/2003017.pdf

West Virginia Community and Technical College System (WVCTCS). (n.d.).Retrieved November 1, 2011 from http://wvctcs.org/

West Virginia Higher Education Policy Commission (WVHEPC) and West Virginia Council for Community and Technical College Education (WVCTCS). (2010). Higher Education Report Card 2010. Retrieved November 1, 2011 from https://www.wvhepc.org/commission/2010_herc.pdf

West Virginia Higher Education Policy Commission (WVHEPC) and West Virginia Council for Community and Technical College Education (WVCTCS). (2009). Higher Education Report Card 2009. Retrieved November 1, 2011 from https://www.wvhepc.org/commission/WebAttachment1.pdf

West Virginia Higher Education Policy Commission (WVHEPC) and West Virginia Council for Community and Technical College Education (WVCTCS). (2008). Higher Education Report Card 2008. Retrieved November 1, 2011 from https://www.wvhepc.org/resources/report\%20cards/final2008reportcard.pdf 
Zembylas, M. (2008 November). Engaging with issues of cultural diversity and discrimination through critical emotional reflexivity in online learning. Adult Education Quarterly, 59 (1), 61-82.

Zhai, L. \& Newcomb, L. (2000). Factors that influence transfer student academic performance and retention [Electronic Version]. Retrieved September 12, 2010 from ERIC database. (ED474482). 